\title{
La cosa juzgada: valor absoluto o relativo
}

\author{
Angel Landoni Sosa \\ "[...] ma quando si tratta di estirpare la mala pianta \\ della frode processuale tutti i mezzi sono buoni». \\ Francesco Carnelutti ${ }^{1}$
}

\section{Concepto}

La cosa juzgada es la cualidad de inimpugnable e inmutable asignada por la ley a la decisión contenida en una sentencia firme dictada en un proceso contencioso con relación a todo proceso posterior entre las mismas partes ( $u$ otras personas afectadas) que verse sobre el mismo objeto y se funde sobre la misma causa.

La cosa juzgada — como lo señalara Liebman ${ }^{2}$ y a quien han seguido numerosos autores -3 no es un efecto de la sentencia sino que es, en rigor, una cualidad que la ley le agrega a aquella a fin de acrecentar su estabilidad.

Cuando a una sentencia se le ha conferido el valor de cosa juzgada, ya no será posible revisar lo decidido, ni pronunciarse sobre su contenido, así sea en el mismo sentido, en un proceso posterior. En presencia de tal sentencia, el juez del proceso ulterior deberá — salvo casos de excepciónabstenerse de fallar sobre el fondo, si existe identidad entre lo ya resuelto

1 Francesco Carnelutti, "Contro il processo fraudolento", en: Rivista di Diritto Processuale Civile, 1926, Parte segunda, pp. 14-25.

2 Enrico Tullio Liebman, Efficacia ed autoritá della sentenza, Ed. Giuffré, Milano, 1935, p. 27.

3 Lino Palacio, Derecho Procesal Civil, Ed. Abeledo - Perrot, Tomo V, p. 499 y autores allí citados.

Hernando Devis Echandía, Teoría General del Proceso, Ed. Universidad, Tomo II, Buenos Aires, 1985, p. 561. 
entre las mismas partes y la nueva pretensión verse sobre idéntico objeto y se funde en la misma causa.

\section{Fundamento}

La necesidad de certeza —enseñaba Couture en «Fundamentos»— ${ }^{4}$ es imperiosa en todo sistema jurídico.

El tema de la impugnación de la sentencia no es otra cosa que una lucha entre las exigencias de verdad y las exigencias de firmeza, ya que de no existir el derecho nunca se sabría en qué consiste. Pero - agregabala necesidad de firmeza debe ceder, en determinadas circunstancias ante la necesidad de que triunfe la verdad. La cosa juzgada no es de razón natural. Antes bien, la razón natural parecería aconsejar lo contrario: que el escrúpulo de verdad sea más fuerte que el escrúpulo de certeza y que siempre, en presencia de una nueva prueba o de un nuevo hecho fundamental antes desconocido, pudiese recorrerse de nuevo el camino andado para restablecer el imperio de la justicia. Y continuaba afirmando: "La cosa juzgada es, en resumen, una exigencia política y no propiamente jurídica: no es de razón natural sino de exigencia práctica».

En el mismo sentido indicaba Gelsi: ${ }^{5}$ "podría considerarse la cosa juzgada, como respuesta o, mejor, solución por vía de determinación, a la incertidumbre en el derecho. Las situaciones jurídicas inciertas, quedan aseguradas, fijadas, precisadas, cuando sobreviene a su respecto una sentencia pasada en autoridad de cosa juzgada. De donde, la función propia de tal instituto no debería conectarse con la justicia, sino con la seguridad, en el campo de los valores jurídicos o de los fines que se procuran por los medios del derecho. Obtenida aquella sentencia, podrá disputarse aun, si el juez erró al dictarla, pero no se podrá dudar que lo establecido por él, es el derecho para el caso resuelto».

4 Eduardo J. Couture, Fundamentos del Derecho Procesal Civil, Ed. Depalma, 1958, pp. 405-408.

5 Adolfo Gelsi Bidart, "Bases positivas para la noción de cosa juzgada”, en: Estudios jurídicos en memoria de Eduardo J. Couture, Montevideo, 1957, pp. 341-361. 


\section{Justicia y certeza}

La posibilidad de revisión de la cosa juzgada pone en aparente colisión intereses fundamentales para la existencia de un sistema jurídico; por un lado, la necesaria inmutabilidad de la cosa juzgada como pilar de la seguridad jurídica y por otra parte, la necesidad de tutelar a la verdad como contenido intrínseco del valor justicia.

Creemos - con Hitters - ${ }^{6}$ que la temática debe plantearse y resolverse en su justo medio, ni una cosa juzgada con toque de divinidad, de carácter infalible e indiscutible, ni una total posibilidad de revisión sin límites de tiempo y de motivos. Por eso la problemática ha de llevarse a su lugar exacto con sincronización de los principios de justicia y seguridad.

\section{Naturaleza jurídica}

La doctrina ha tratado de explicar la cosa juzgada de diversas formas: como ficción de verdad, como presunción de verdad, tesis que hoy han sido superadas, pero que aún perduran en algunos de nuestros códigos civiles.

El meollo de la cuestión radica en desentrañar la esencia de la cosa juzgada y para ello es necesario determinar si la cosa juzgada obliga bajo la forma de un derecho nuevo, no existente antes de la sentencia (función creativa), o si, por el contrario, eso ocurre por la mera declaración (función declarativa) de los mismos derechos que se hallaban instituidos en el ordenamiento jurídico.

Couture $^{7}$ señalaba que existen dos posiciones opuestas:

«Por una parte se sostiene que la sentencia y su consecuencia, la cosa juzgada, no constituyen sino una determinación concreta del derecho material o sustancial existente antes del proceso. Es el mismo derecho anterior, actualizado y hecho indiscutible en el caso decidido. $Y$ lo que da su principal acento a esa nueva forma del derecho, es el carácter de obligatoriedad y de vinculación que reviste frente al

6 Juan Carlos Hitters, Revisión de la cosa juzgada, Librería Editora Platense SRL, 1977, p. 172.

7 Eduardo J. Couture, Fundamentos [...], op. cit., p. 410. 
juez de cualquier otro litigio futuro que pudiera provocarse sobre el mismo tema. Nada ha alterado el derecho anterior; solo ha sido aplicado; nada hay de nuevo, solo situaciones impeditivas de la revisión en un nuevo proceso, ligan al juez que eventualmente pudiera ser llamado a conocer de él.

Frente a esa orientación se halla otra que advierte en la cosa juzgada un poder vinculatorio diverso de la simple declaración del derecho anterior. La cosa juzgada, se sostiene, no encuentra su eficacia en el derecho sustancial preexistente a la sentencia, sino en la fuerza de la sentencia misma una vez que ésta se ha hecho indiscutible. Pasado en cosa juzgada el fallo, ha nacido en el orden del derecho una nueva norma. Su eficacia vinculatoria emana de ella misma y no de la norma sustancial anterior. Hasta puede darse el caso de que esa norma no coincida, por diversas circunstancias, con el derecho sustancial; y aun así, la cosa juzgada es obligatoria y eficaz».

En el derecho uruguayo ha habido ejemplos que permitirían avalar esta segunda tesis.

Así, nuestra jurisprudencia aplicó las astreintes mucho tiempo antes de que un texto legal las consagrara. Lo mismo ocurrió cuando se desechó la tesis nominalista y se procedió al reajuste de las obligaciones afectadas por la inflación, sin que existiera texto legal que lo habilitara.

Devis Echandía ${ }^{8}$ en tesis ecléctica, señalaba que la cosa juzgada tiene naturaleza procesal, porque es una consecuencia del proceso y la emanación de la voluntad del Estado manifestada en la ley procesal.

Pero sus efectos jurídicos -en su opinión - se extienden también indirectamente fuera del proceso y sobre las relaciones jurídicas sustanciales, como una consecuencia de la inmutabilidad de la decisión, que es su efecto directo, produciendo así la definitividad de la certeza jurídica de aquella.

Ambos son efectos jurídicos de la cosa juzgada; directo y procesal la inmutabilidad de la decisión; indirecto y sustancial la definitividad de la certeza jurídica del derecho sustancial declarado o rechazado.

8 H. Devis Echandía, Teoría general del proceso, op.cit., p. 561. 


\section{Los efectos de la cosa juzgada}

\subsection{El efecto negativo o impeditivo}

La cosa juzgada tiene un efecto negativo que prohíbe a los jueces decidir sobre lo ya resuelto, es decir, que impide toda decisión judicial futura que verse sobre el mismo objeto, tenga idéntica causa y sea entre las mismas partes o personas a las que la cosa juzgada afecte.

El referido efecto negativo ha sido consagrado en el Art. $219^{\circ} \mathrm{del}$ Código General del Proceso uruguayo (Código Modelo Art. $193^{\circ}$ en redacción similar), que dispone: «efecto de la cosa juzgada en otro proceso. La cosa juzgada, obtenida en proceso contencioso, tendrá efecto en todo proceso entre las mismas partes siempre que versare sobre el mismo objeto y se fundare en la misma causa.»

La exclusión del proceso posterior o, en todo caso, del pronunciamiento de fondo en el mismo, - como lo señala Ortells — ${ }^{9}$ se debe producir tanto si se formula la pretensión procesal en el mismo sentido en que se propuso en el proceso anterior, lo que puede ocurrir si aquella fue desestimada y se insiste en reproponerla con diferencias que no determinan un objeto diferente. Como si se plantea como una pretensión dirigida a obtener la declaración contraria sobre el objeto del pronunciamiento que adquirió cosa juzgada, que es la posible reacción del demandado ante una sentencia estimatoria de la pretensión.

\subsection{El efecto positivo o prejudicial}

La cosa juzgada otorga definitividad a la declaración de certeza contenida en la sentencia, haciéndola indiscutible en nuevos procesos, salvo casos de excepción, como más adelante procederemos a su análisis.

La referida definitividad de la declaración de certeza implica, además, el deber de ajustarse a lo ya decidido, si ello es condicionante o prejudicial sobre la pretensión pendiente de juzgar. Pueden ser ejemplos de esta última situación, entre otros, los siguientes:

a) la declaración positiva o negativa de una relación de filiación respecto de una ulterior pretensión de condena por alimentos entre familiares;

9 Manuel Ortells Ramos, Derecho Procesal Civil, Ed. Aranzadi, 2a edición, 2001, p. 600. 
b) la declaración de validez o de nulidad de un testamento respecto de la condena a la entrega de un legado dispuesto en el mismo.

\section{Los alcances de la cosa juzgada}

\subsection{El límite subjetivo}

Al respecto el Art. $218^{\circ}$ del C.G.P. (Código Modelo Art. $196^{\circ}$, en redacción casi idéntica) dispone:

«Eficacia de la sentencia frente a terceros.

$218^{\circ} .1$-La cosa juzgada alcanza a la partes y a sus sucesores a título universal.

$218^{\circ} .2$-También alcanza a: a) a los codeudores solidarios; b) a los titulares del dominio desmembrado cuando se refiere a un desmembramiento que no es el propio respecto del mismo bien.

$218^{\circ} .3$-Los socios, los comuneros, los terceros de cuyos derechos dependen los de las partes, aquellos cuyos derechos dependen de estas, o del acto o del contrato cuya validez o eficacia ha sido juzgada, son terceros a los que alcanza la cosa juzgada solamente si han tenido conocimiento judicial del pleito o si se amparan a la decisión en la primera oportunidad de que dispongan. También comprenderá a los que pudieron conocer a la cuestión debatida en el proceso en virtud de información registral, la hubieren o no solicitado».

\subsubsection{Análisis de las diversas situaciones planteadas por el texto legal}

A) La cosa juzgada alcanza a las partes y a sus sucesores a título universal.

Por parte debe interpretarse lo sustancial, es decir, la persona que deduce la pretensión en nombre propio o en cuya representación se hace valer $y$ aquella frente a quien se interpone.

Por consiguiente, en los casos de representación (de personas físicas o de actuación de personas jurídicas a través de sus órganos) la cosa juzgada es eficaz respecto del representado, no del representante.

Corresponde destacar que la noción de parte engloba al actor, al demandado, a los terceros coadyuvantes, excluyentes y aquel cuyo emplaza- 
miento se practicó conforme al Art. $51^{\circ} \mathrm{del} \mathrm{C.G.P.} \mathrm{que} \mathrm{consagra} \mathrm{la} \mathrm{inter-}$ vención necesaria por citación.

La cosa juzgada también afecta a los sucesores a título universal, pero para ello es necesario que el causante haya fallecido con posterioridad al emplazamiento, pues si el deceso ocurrió antes de dicho acto, la demanda debió ser dirigida contra los herederos, bajo apercibimiento de nulidad insanable por vicio en el emplazamiento (C.G.P. Art. 129.1, Código Modelo Art. 119\%.1).

En caso de transmisión por acto entre vivos de la cosa litigiosa dispone el Art. $35^{\circ} .2$ que el sucesor podrá sustituir a la parte en el proceso salvo que se oponga la contraria, en cuyo caso el tribunal resolverá.

Aceptada la sustitución la cosa juzgada afectará al sucesor a título singular en su calidad de parte.

B) También afecta a los codeudores solidarios y a los titulares del dominio desmembrado cuando se refiere a un desmembramiento que no es el propio respecto del mismo bien.

En ambas hipótesis, la cosa juzgada los afecta aun cuando no hayan tenido conocimiento judicial del proceso.

En el supuesto del dominio desmembrado si se ha fallado, por ejemplo, respecto de la nuda propiedad, ello alcanza al titular de otro derecho real limitado (por ejemplo, el del usufructuario). Este no podría discutir lo ya decidido respecto de los derechos del nudo propietario.

Como señala Barrios de Angelis: ${ }^{10}$

«[...] más que una extensión de los efectos de la cosa juzgada (en el sentido de que la sentencia declare, modifique o extinga un derecho propio) la norma es una confirmación de su falta de legitimación para intervenir a favor o en contra de lo decidido".

C) Los casos contemplados en el Art. $218^{\circ} .3$ (C.Modelo Art. 192.3).

La disposición distingue dos situaciones: por un lado, aquella en la cual el tercero se ampara en la cosa juzgada y aquella otra, en que la cosa

10 Dante Barrios de Angelis, El proceso civil, Ed. IDEA, 1989, p. 177. 
juzgada se extiende al tercero, es decir, lo alcanza cuando se dan — según el caso- dos hipótesis posibles: a) el tercero tuvo conocimiento judicial del pleito y b) el tercero pudo conocer de la cuestión debatida en virtud de información registral.

\section{C.1.) El amparo del tercero a la cosa juzgada}

En este supuesto no interesa la forma en que el tercero conoció la decisión que lo favorece y que habilita su amparo a la cosa juzgada. Basta con que demuestre interés y se ampare a la eficacia de la sentencia invocando la circunstancia de pertenecer a alguna de las categorías mencionadas en la norma.

Conforme al texto legal dicho amparo debe efectuarse en la primera oportunidad de que se disponga y puede realizarse válidamente hasta tanto no operen los efectos extintivos de la prescripción.

\section{C.2.) Afectación por la cosa juzgada en razón del conocimiento judicial del pleito.}

En nuestra opinión, no basta con el mero conocimiento, como podría ocurrir en el caso de un testigo que se enterara del proceso al concurrir a declarar, sino que además es necesario que no se violen las garantías del debido proceso, esto es, el afectado deberá tener una oportunidad razonable para articular sus defensas y producir pruebas.

Véscovi y colaboradores ${ }^{11}$ indican que solo cuando un texto legal impone dar conocimiento judicial al tercero sería de aplicación el Art. $218^{\circ} .3$. En tal sentido refieren, a vía de ejemplo, los arts. $53^{\circ}$ y $54^{\circ}$ del C.G.P., ${ }^{12}$ los artículos $47^{\circ}$ y $40^{\circ}$ de los Decretos Leyes No 14.219 y 14.384 , que imponen la colocación de un cedulón genérico que comunica el decreto de desalojo del inmueble urbano o rural a los ocupantes a cualquier títu-

11 Enrique Véscovi y colaboradores, Código General del Proceso, Ed. Ábaco, agosto, 2000, Tomo 6, p. 346.

12 C.G.P. Art. 53: Denuncia de terceros: El demandado, en un proceso en el que considere que otra persona, además o en lugar de él, tiene alguna obligación o responsabilidad en la cuestión controvertida, debe denunciarlo, indicando su nombre y domicilio, a los efectos de que se le noticie del pleito, bajo responsabilidad de los daños y perjuicios que correspondieren por su omisión. 
lo, el Art. $369^{\circ}$ de la Ley de sociedades No 16.060 que prevé en el proceso de impugnación de asambleas de sociedades anónimas la publicación de edictos por tres días a fin de posibilitar la intervención de los sujetos interesados que pretendan coadyuvar con el impugnante o con la sociedad, y el Art. $370^{\circ}$ de la misma ley que establece que los efectos de la sentencia obligan a todos los accionistas hayan o no comparecido.

En el mismo sentido el emplazamiento genérico que se efectúa para la prescripción treintenaria (C.G.P. Art. $127^{\circ} .4$ ) y para la acción de inconstitucionalidad (C.G.P. arts. $517^{\circ} .1$ y $521^{\circ}$ ) posibilitan extender los efectos de la sentencia en base al Art. $218^{\circ} .3$.

No extensión de la cosa juzgada a terceros cuando no se tuvo conocimiento judicial del proceso.

En tal sentido, resulta oportuno referir que la Suprema Corte de Justi$\mathrm{cia}^{13}$ acogió por unanimidad un recurso de casación en un proceso en el que se pretendía extender la eficacia de una sentencia que había decidido la nulidad de una escritura de compraventa de un inmueble, a los terceros que habían sido adquirentes con posterioridad y que no habían tenido conocimiento judicial del pleito.

En dicho fallo la Suprema Corte expresó:

«En el sublite se trata de extender ilegítimamente la eficacia de la sentencia precedentemente referida contra terceros que, a la postre, adquirieron a XX los inmuebles y quienes no fueron parte en el referido juicio. La situación de estos terceros no encuadra en las excepciones al principio contenido en el acápite del Art. $479^{\circ}$ del CPC de que "La sentencia debe concretarse en su literal disposición a las partes en litigio", como tampoco ingresa en ninguna de las previsiones legales del Art. $218^{\circ}$ del C.G.P.; es más, la pretendida extensión está en el nuevo ordenamiento procesal expresamente vedada: "Son terceros a los que alcanza la cosa juzgada solamente si han tenido conocimiento judicial del pleito o si se amparan a la decisión en la primera

C.G.P. Art. 540: Llamamiento de oficio en caso de fraude o colusión: En cualquiera de las instancias, siempre que se presuma fraude o colusión en el proceso, el tribunal de oficio o a petición del Ministerio Público o de parte, ordenará la citación de las personas que puedan ser perjudicadas para que hagan valer sus derechos, pudiéndose, a tal fin, suspender el proceso hasta por cuarenta días.

13 La justicia uruguaya, Tomo 109, Caso No 12.612, Sentencia del 29/1 1/1993. 
oportunidad de que dispongan» (Art. 218 .3 ), situaciones en las que no se encuentran los demandados de autosm. ${ }^{14}$

Idéntica tesis fue la sostenida por nuestro máximo Tribunal en fallo del 12 de noviembre de $1997,{ }^{15}$ donde reiterando conceptos ya vertidos en la sentencia No 73 del mismo año indicó:

"[...] en principio, es posible la extensión de la cosa juzgada a otras personas que tienen con la condenada un cierto grado de relación. En función de la fecha de la sentencia y a lo dispuesto por la Ley 16.060 (Art. $511^{\circ}$ ), esa extensión subjetiva de la pretensión ejecutiva era posible (ejusdem Art.77o; además Código General del Proceso Art. $\left.218^{\circ}\right) \%$.

"Claro, en el caso de los socios, ello es posible -como en el caso de todos los demás terceros que se enumeran en el Art.218 .3 del citado cuerpo legal- «[...] solamente si han tenido conocimiento judicial del pleito[...]», que no es sino en la etapa inicial del proceso pues el fundamento de esta exigencia, «[...] no puede ser otro que el de permitir la plena intervención [...]" (Dante Barrios de Angelis, en Curso de Derecho Procesal T.3 p.28) o también, "[...] si se han amparado a la decisión en la primera oportunidad de que dispongan[...]." Y ninguna de estas hipótesis es la de autos».

«No fueron parte en el proceso principal -o etapa de pleno conocimiento- pues la demanda se dirigió contra XX S.R.L. y ni siquiera fueron noticiados posteriormente y menos aún se ampararon a la cosa juzgada, razón por la cual dicha extensión de la cosa juzgada no es admisible».

14 Como detalle anecdótico cabe referir que en el caso la madre había realizado una partición con su hijo, que luego fue declarado incapaz, y casi simultáneamente el mencionado hijo había procedido a la venta de sus bienes a dos personas respecto de las cuales la madre, que había realizado la referida partición con una anticipación de seis días a la referidas ventas, pidió posteriormente la nulidad de dichas escrituras, pretensión que fue acogida, y luego intentó hacer extensiva la nulidad decretada a los antes mencionados compradores, sin haberlos citado al juicio.

15 La justicia uruguaya, Tomo 117, Caso No 13.450. 
C.3.) Extensión de la cosa juzgada en razón del conocimiento registral.

El Art. $218^{\circ} .3$ in fine establece que: «También comprenderá a los que pudieron conocer la cuestión debatida en el proceso en virtud de información registral la hubieren o no solicitado".

El tema está vinculado con la existencia o no de buena fe por parte de los terceros, dado que si estos pudieron tener conocimiento respecto de la situación de los bienes a través de la información registral y no lo hicieron, la cosa juzgada los afectará.

Nuestro ordenamiento jurídico, ha ido incorporando una serie de demandas que deben ser registradas por las consecuencias que ellas producen sobre las situaciones jurídicas involucradas y las que han sido ampliadas por la Ley de registros No 16.871 de 28 de setiembre de 1997, vigente desde el $1^{\circ}$ de mayo de 1998.

La referida ley en su Art. $17^{\circ}$ establece que en el registro de la propiedad Sección Inmobiliaria se inscribirán:

«No 8: Las demandas y sentencias ejecutoriadas que tengan por objeto el reconocimiento de derechos en relación con bienes inmuebles, que afecten o puedan afectar los derechos registrados o que se registren en el futuro.

No 9: Los embargos específicos y demás medidas cautelares que dispongan los Jueces, siempre que tengan relación con bienes inmuebles.»

La misma ley en su Art. $25^{\circ}$ dispone que en el registro nacional de vehículos automotores - dependiente del registro de la propiedad sección mobiliaria - se inscribirán:

- Los embargos específicos y demás medidas cautelares que dispongan los tribunales, que afecten los poderes de decisión de los titulares de derechos inscriptos.

- Las demandas y las sentencias ejecutoriadas que tengan por objeto el reconocimiento de derechos en relación con el vehículo automotor que afecten o puedan afectar los derechos registrados o que se registraren en el futuro.

Asimismo dicha ley entre los actos inscribibles en el registro nacional de actos personales sección interdicciones contempla en su Art. $35^{\circ}$ los siguientes: 
1. Las interdicciones, limitaciones generales a la facultad de disposición y demás medidas cautelares relativas a la persona natural o jurídica decretadas por los jueces, en los casos, formas y alcances previstos por la ley.

2. Los embargos generales de derecho.

3. La pérdida, suspensión, limitación y restitución de la patria potestad y los convenios de los padres sobre la administración de los bienes de sus hijos bajo su patria potestad.

4. Las pretensiones de prescindencia de la personalidad jurídica de una sociedad a las que hace referencia el Art. $191^{\circ}$ de la Ley No 16.060 del 4 de setiembre de 1989.

En la sección regímenes matrimoniales se prevé -Art. $39^{\circ}$ No 2 - la inscripción de los casos de disolución de la sociedad conyugal.-

En la sección universalidades del citado registro de actos personales se inscriben, entre otros:

Art. $45^{\circ}$ No 3: la demanda de petición de herencia y toda otra acción reivindicatoria a título universal.

Art. $45^{\circ} \mathrm{N}^{\circ} 7$ : la acción pauliana y la dispuesta por el Art. $1066^{\circ} \mathrm{del}$ C. Civil, cuando tengan por objeto la rescisión o revocación de enajenaciones del todo o parte de una universalidad jurídica. El plazo para inscribir estas acciones caducará en el término de un año, a partir de la fecha de inscripción del acto impugnado.

La doctrina uruguaya señala ${ }^{16}$ la importancia que ha adquirido la parte final del Art. $218^{\circ} .3$ pues leída dicha norma en consonancia con la legislación registral, produce relevante extensión del alcance subjetivo de la cosa juzgada.

El sistema, así diseñado, termina vinculando de modo eficaz la normativa registral con la procesal, adecuándose al amplio campo de información accesible que comporta el moderno régimen de inscripciones, de incidencia clave en el ámbito de la circulación de bienes y servicios, y por ende, de consulta exigible a todo sujeto que actúe con mediana diligencia y buena fe.

Es en protección de ese sistema, de esos principios y del de seguridad en la contratación - se afirma - que se incorporó la parte final del Art. $218^{\circ} .3$ conectando de modo coherente los aspectos procesales, registrales y sustanciales involucrados.

16 Enrique Véscovi y colaboradores, Código General del Proceso, op.cit., p. 349. 
La Suprema Corte de Justicia en reciente Sentencia No 250 del 2 de noviembre de 2001, haciendo lugar a un recurso de revisión señaló que el adquirente conocía el cuestionamiento de la titularidad del bien y la alegación de la simulación antes del remate efectuado, y ello resultaba:

a) De la circunstancia que los terceristas en la ejecución habían denunciado en ella la existencia del juicio de nulidad por simulación y acción pauliana.

b) Dichos terceristas habían incorporado en los autos constancia de inscripción del oficio librado al registro general de Inhibiciones comunicando las acciones de nulidad entabladas.

c) El juez con carácter previo al remate ordenó que: «[...] En atención a la existencia de una inscripción de acción pauliana en el Registro respectivo deberá el Sr. Rematador prevenir a los compradores, alertándoles respecto de dicha inscripción. Debiendo igualmente la Sra. Alguacil por escrito dando cuenta del cumplimiento de dicha asignación», lo cual fue efectivamente cumplido, según surge del acta de remate de fs. 242 del expediente.

"Las circunstancias relacionadas llenan, en opinión de la Corte, la exigencia del Art. $218^{\circ} .3$ C.G.P [...] habiendo permitido al adquirente conocer oportunamente la situación existente y el consiguiente riesgo".

Cabe añadir todavía que en la hipótesis prevista en la parte final del referido Art. $218^{\circ} .3$ basta la posibilidad de conocer «la cuestión debatida" a través de la información registral para que opere la extensión de la cosa juzgada, esto es, no se requiere conocimiento judicial alguno.

Consecuentemente, en vista de la inscripción de la acción pauliana efectuada con anterioridad al remate, el adquirente está alcanzado por la cosa juzgada relativa a la invalidez de la ejecución y a la no titularidad dominial de la vendedora aún cuando - contra lo indicado antes- pudiera sostenerse que el conocimiento resultante del aviso efectuado en el momento del remate no cumplió con la exigencia prevista en la primera hipótesis de la norma, por no tratarse de un «conocimiento judicial» habilitante de una defensa eficaz.

La Suprema Corte llega a la conclusión de que el adquirente no puede ser considerado de buena fe, ya que al momento del remate conocía el 
proceso de simulación pendiente, por lo cual no podía tener la seguridad de que estaba adquiriendo el inmueble a su verdadero propietario.

\subsection{El límite objetivo.}

El Art. $219^{\circ}$ del C.G.P., ya citado, exige para que opere la cosa juzgada en su efecto negativo o impeditivo, que se haya obtenido en proceso contencioso y que se dé en la especie la denominada regla de la triple identidad respecto de los sujetos, del objeto y de la causa.

La mencionada identidad entre los sujetos activos y pasivos debe existir con prescindencia de la posición que los mismos hayan ocupado en el proceso anterior y tengan en el ulterior.

En tal sentido, la cosa juzgada sería de aplicación en las siguientes hipótesis:

a) en un primer proceso acciona una persona reivindicando un bien y el demandado se defiende aduciendo la prescripción, obteniendo el primero una sentencia favorable y rechazándose la excepción. Resulta claro, que el perdidoso no podría intentar, con éxito, un nuevo proceso esgrimiendo la prescripción, pues ya existe cosa juzgada sobre el punto, con independencia de la actual posición de las partes en el nuevo proceso.

b) en otro caso, un sujeto pretende el cumplimiento de un contrato y el demandado esgrime la excepción de contrato no cumplido, la que es desestimada. Dicha decisión impide que el vencido pueda pretender, con éxito, la resolución del contrato por incumplimiento.

\subsubsection{Identidad del objeto y de la causa}

$\mathrm{El}$ análisis de la identidad del objeto requiere necesariamente el examen de la causa, ya que no es suficiente que las pretensiones versen sobre un mismo bien de la vida, ya que si la causa invocada es diferente no será de aplicación la cosa juzgada.

Así, nuestra jurisprudencia ha entendido ${ }^{17}$ que no hay identidad objetiva y, por ende, no existe cosa juzgada entre dos procesos en que se pretenda el mismo bien, si en uno posterior se adujo como causa la reivindi-

17 La justicia uruguaya, Tomo 90, Caso No 10.329 y Tomo 101, Caso No 11.482. 
cación invocando la calidad de titular del dominio del bien y en el otro, anterior, se había solicitado y obtenido el desalojo invocando la calidad de comodatario precario del ocupante del bien.

Como se puede apreciar el límite objetivo lo forman, en conjunto, el objeto y la causa pretendida; si aquel es el mismo (inmueble, por ejemplo) pero la causa varía (prescripción en vez de la adquisición por compraventa) ya no existirá identidad objetiva entre ambos procesos, ni tampoco cosa juzgada. ${ }^{18}$

Corresponde advertir que la cosa juzgada, en cuanto al objeto se refiere, se extiende a aquellos puntos que sin haber sido materia expresa de la decisión, por ser su consecuencia necesaria, resultan resueltos tácitamente, por ejemplo, si la sentencia condenó a la restitución del bien y nada dijo sobre el pago de frutos, debe entenderse que el demandado quedó absuelto de ellos.

\subsubsection{La cosa juzgada se debe haber producido en un proceso contencioso anterior con sentencia firme}

La norma excluye de la autoridad de la cosa juzgada a las providencias dictadas en los procesos voluntarios y a su vez permite que la cosa juzgada pueda a su vez invocarse en todos los procesos ulteriores cualquiera sea su estructura, ya sea contenciosa o voluntaria siempre que se de la regla de la triple identidad.

\section{La cosa juzgada y los intereses difusos ${ }^{19}$}

\subsection{Introducción}

De todas las complejidades que plantea la fuerte irrupción de los intereses difusos y colectivos en la sociedad y, como consecuencia en el dere-

18 Cfr. H. Devis Echandía, Teoría General del proceso, op.cit., Tomo II, p. 574.

19 Reiteramos aquí gran parte de los conceptos vertidos en el estudio que realizáramos con el Profesor doctor Santiago Pereira Campos para el Congreso Internacional de Derecho Procesal que tendrá lugar en Roma del 16 al 18 de mayo de 2002 en el Centro di Studi Giuridici Latinoamericani de la Universitá "Tor Vergata», y que denominamos «Tutela de los intereses colectivos y difusos en el Uruguay». 
cho, la que presenta mayores dificultades es la relativa a los efectos de la cosa juzgada.

La doctrina procesal uruguaya ha dedicado esfuerzos al concepto de intereses difusos y colectivos y a la legitimación para defenderlos. No obstante, han sido escasos los estudios dedicados al análisis de los efectos de la cosa juzgada en estos procesos. ${ }^{20}$

Por ello, nuestras conclusiones al respecto deben considerarse solo aproximaciones provisorias a un tema difícil, donde una única y escueta norma legal —el Art. $220^{\circ}$ del CGP $-{ }^{21}$ deja planteadas grandes interrogantes cuyas respuestas en uno u otro sentido proyectan importantes consecuencias sobre el sistema procesal y, por ende, deben ser adoptadas con gran cautela. Será menester, por ello, que la doctrina procesal prosiga e intensifique el análisis del punto en Uruguay, no debiendo descartarse reformas legislativas en este sentido.

Apartándose del principio por el cual el fallo vincula exclusivamente a las partes que intervinieron en la litis, ante la naturaleza tan particular del objeto e intereses de estos procesos, se prevé que, de regla, los efectos de la sentencia se proyectan «erga omnes». De este modo, se establece una excepción al tradicional principio de que la cosa juzgada solo alcanza a las partes intervinientes.

De acuerdo con las previsiones del Art. $220^{\circ}$ - cuya fuente es la legislación brasileña al igual que la del Art. 1940 del Código Modelo-, pueden distinguirse claramente tres situaciones:

20 E. Véscovi, M. De Hegedus, S. Klett, L. Simón, F. Cardinal y S. Pereira Campos, "Código [...]", op. cit., t. 6, comentario al Art. 220 ; A. Landoni, «La tutela de los derechos del consumidor en el derecho uruguayon, en: Estudios de derecho procesal en homenaje al profesor doctor Enrique Véscovi, FCU, Montevideo, 2000, p. 281 y ss.; y «Legitimación para la defensa de los intereses difusos», en: RUDP 4/81, p. 350 y ss.; S. Pereira Campos, "Intereses difusos y efectos de la cosa juzgada», en: Estudios de derecho procesal en homenaje al profesor doctor Enrique Véscovi, op. cit., p. 313 y ss.; e «Intereses difusos y colectivos en Uruguay: marco conceptual, legitimación y efectos de la cosa juzgadan, en: RUDP 2/2000.

21 Art. $220^{\circ}$. Efectos de la cosa juzgada en procesos promovidos en representación de intereses difusos: «La sentencia dictada en procesos promovidos en defensa de intereses difusos (Art. 420) tendrá eficacia general, salvo si fuere absolutoria por ausencia de pruebas, en cuyo caso, otro legitimado podrá volver a plantear la cuestión en otro proceso". 
A) La pretensión es acogida: la sentencia pasa en autoridad de cosa juzgada para todos los miembros de la colectividad, tendrá eficacia general. ${ }^{22}$

B) La pretensión es rechazada por inexistencia de fundamentos: también aquí los efectos se producen "erga omnes", de forma tal que la pretensión ya no podrá volver a ser planteada por igual fundamento, aunque lo fuese por iniciativa de otro interesado. ${ }^{23}$

C) La pretensión es rechazada por ausencia o insuficiencia de prueba: la sentencia no pasará en autoridad de cosa juzgada respecto de los no litigantes (sí respecto de los que litigaron) y cualquier otro interesado podrá volver a plantear la cuestión en otro proceso, sin preverse plazo alguno para ello. En este caso, a nuestro juicio el otro legitimado podrá demandar invocando igual o distinto fundamento y -obviamenteaportando y produciendo nueva prueba. En esta hipótesis los efectos de la cosa juzgada siguen los principios generales: solo alcanza a los litigantes intervinientes.

La sentencia que se dicte en el nuevo proceso que tramite otro interesado, a su vez, tendrá eficacia «erga omnes» o no, según se verifiquen en este nuevo proceso las hipótesis señaladas en los literales A, B y C precedentes, según corresponda.

22 No resuelve la norma del Art. $220^{\circ}$ en forma expresa qué sucede cuando la pretensión es acogida parcialmente.

En nuestra opinión, en caso de que la pretensión sea acogida en parte y desestimada en parte, cabe regirse por los siguientes criterios:

a) Sobre la parte acogida regirá el efecto general.

b) Sobre la parte desestimada por falta de fundamento también regiría el efecto general.

c) Sobre la parte desestimada por falta o insuficiencia de prueba, no regirían los efectos generales y otro legitimado podría replantear la cuestión en otro proceso.

23 Se requerirá en este caso, para que sea posible iniciar otro proceso, que se invoque una diversa "causa petendiny así no quedar alcanzado el nuevo interesado por los efectos de la cosa juzgada de la sentencia ya dictada. Al respecto, resulta preciso advertir que el tribunal debe guardar especial cuidado al momento de identificar la nueva pretensión deducida, indagando sus elementos en profundidad a efectos de determinar si la misma conlleva un fundamento distinto de la cuestión ya resuelta y por ende el accionante no se halla alcanzado por la cosa juzgada de la sentencia dictada en el proceso anterior o si, por el contrario, el nuevo litigante pretende «disfrazar» como una nueva "causa petendi» aquello que en realidad fue resuelto antes y sobre lo cual se extienden los efectos de la cosa juzgada de la sentencia ya dictada. 
Las soluciones del Art. $220^{\circ}$ en cuanto al efecto de la cosa juzgada en caso de rechazo de la pretensión en la sentencia $(\mathrm{B}$ y $\mathrm{C})$ permiten conciliar con un adecuado equilibrio los intereses en juego, evitando los riesgos de soluciones extremas. En efecto, si se limitara el alcance de la cosa juzgada al legitimado que dedujo la pretensión, existe el riesgo de que el litigio se reitere con manifiesto detrimento para la economía procesal y sensibles perjuicios para la actividad de la persona física o jurídica de la que emana, sujeta a que la perturbación pueda ser reiterada. En cambio, si, por otro lado, se extendiera aquel ámbito, sin ninguna restricción, a todos los eventuales colegitimados, esto es, a los restantes interesados, se posibilitaría la maniobra de que propuesta la acción mal fundamentada y mal instruido el proceso por un interesado en colusión con los responsables del acto, se podría alcanzar el objetivo ilícito de que mediante el rechazo de lo peticionado quedase a salvo el legitimado pasivo.

\section{2. ¿Cómo incide en otro interesado el alcance general de la sen- tencia?}

La cuestión que, a nuestro juicio, ofrece las mayores dificultades es determinar cómo incide la extensión de los efectos de la cosa juzgada de la sentencia, cuando en las distintas situaciones que pueden plantearse otros interesados quieren hacer valer tales efectos.

Para la solución de los casos concretos a la luz de la norma comentada, es menester considerar cada situación, desde el punto de vista del objeto del proceso y de los sujetos que participaron en el mismo. El contenido de la decisión variará, por supuesto, según el objetivo que se persigue y la pretensión que se deduzca.

La protección de estos intereses debe ser, además, fundamentalmente preventiva; la rapidez y eficacia con que se debe actuar harán necesario muchas veces adoptar medidas cautelares innovativas o provisorias y anticipativas de la decisión final.

Con carácter general, debemos señalar que los efectos de la sentencia obtenida por un interesado no se aplican siempre en forma "automática» a los demás interesados que no litigaron y, por ende, muchas veces se requerirá la tramitación de otro proceso, aunque con objeto más limitado.

Veamos los distintos supuestos: 
A) Se acciona buscando la protección de los intereses difusos (o colectivos), para la prevención de un dańo grave e inminente, y/o la cesación de perjuicios actuales susceptibles de prolongarse.

Así, por ejemplo, se intenta paralizar los procesos de emanación o desecho de elementos contaminantes del medio ambiente o cualesquiera otras consecuencias que vulneren el equilibrio ecológico o que lesionen, perturben o amenacen valores estéticos, históricos, artísticos, urbanísticos, arquitectónicos, arqueológicos o paisajísticos; o neutralizar la circulación comercial de productos defectuosamente elaborados, o disponer su exclusión del mercado de consumo cuando, por no reunir los recaudos necesarios de calidad y seguridad, comprometieren la indemnidad personal o patrimonial de los consumidores, etc.

Este caso no plantea demasiadas complejidades en cuanto a los efectos sobre terceros de la cosa juzgada, porque el fallo que satisface a un legitimado suele satisfacer automáticamente a los demás. En otras palabras, si la sentencia dictada en el proceso iniciado por un legitimado en defensa de los intereses difusos obtiene la prevención de un daño (porque, por ejemplo, evita que se viertan elementos contaminantes a un cauce de agua) o el cese de los perjuicios (porque, se detiene el proceso contaminante que venía realizando una fábrica), de por sí ese resultado generalmente dará satisfacción a los demás interesados no litigantes, sin necesidad de nuevo proceso.

De todos modos, si por las características de la condena, otro interesado requiriera o deseara además expresa constancia de que se encuentra alcanzado por el fallo, podría tramitar otro proceso (de regla: ordinario) para obtener una sentencia declarativa Art. $11^{\circ} .3$ del CGP ${ }^{24}$ de que se encuentra alcanzado por la cosa juzgada de aquella sentencia. Pero, reiteramos, por las propias características de la condena (a hacer o dejar de hacer algo), el efecto a los terceros se extiende de hecho, por lo cual no será necesario el nuevo proceso.

Si el fallo desestimara la demanda por carecer de fundamentos, obviamente la eficacia de la sentencia será también general abarcando a los demás interesados.

24 Dispone que «el interés del demandante puede consistir en la simple declaración de la existencia o inexistencia de un derecho -en este caso el derecho que surge de la sentencia dictada en otro proceso y que lo alcanza - aun cuando este no hubiera sido violado o desconocido, o de una relación jurídica [...]». 
En cambio, si el motivo de la desestimación fuera la ausencia o insuficiencia de pruebas, los otros legitimados no se verán alcanzados por la sentencia y podrán volver a plantear la cuestión en otro proceso.

B) Se acciona para obtener la reparación de los daños colectivos o difusos. Aquí, cabe distinguir dos situaciones:

a) La reparación en especie esto es la reposición de las cosas al estado anterior al menoscabo.

La reposición de las cosas al estado anterior tendrá lugar siempre que sea posible reparar en especie el menoscabo a los intereses colectivos o difusos (sin perjuicio del resarcimiento pecuniario de los daños globales o individuales subsistentes). Así, por ejemplo, la adopción de las medidas idóneas para recomponer el equilibrio de los valores ecológicos u otros bienes comunes a la colectividad perjudicada o la rectificación de la publicidad engañosa por los mismos medios y modalidades empleados en el mensaje irregular, o la corrección de sus términos para una adecuada información a los consumidores.

En este caso, respecto de la incidencia de la extensión a terceros de los efectos de la sentencia, pueden realizarse las mismas consideraciones que las expuestas para el caso de la acción de protección mencionada antes. Básicamente, si la sentencia dictada en el proceso iniciado por un legitimado en defensa de los intereses difusos obtiene la reparación en especie total o parcial de un daño (porque por ejemplo se obtiene que la empresa contaminante de un río realice el proceso de descontaminación), de por sí ese resultado generalmente dará satisfacción a los demás interesados no litigantes, sin necesidad de nuevo proceso. ${ }^{25}$

b) La reparación pecuniaria, o sea el resarcimiento en dinero del daño globalmente producido a la colectividad interesada.

Esta categoría de reparación es discutida en derecho comparado y no

25 Ello sin perjuicio de que, si por las características de la condena, otro interesado requiriera o deseara además expresa constancia de que se encuentra alcanzado por el fallo, podría tramitar un proceso (de regla: ordinario) para obtener una sentencia declarativa (Art. $11^{\circ} .3$ del CGP) de que se encuentra alcanzado por la cosa juzgada de esa otra sentencia.

Obvio es ya decir que si el fallo desestimara la demanda por carecer de fundamentos, la eficacia de la sentencia será también general abarcando a los demás interesados.

$\mathrm{Si}$, en cambio, el motivo de la desestimación fuera la ausencia o insuficiencia de pruebas, otro legitimado podrá volver a plantear la cuestión en otro proceso. 
existen antecedentes sobre la misma en nuestro país, ni estudios de la doctrina al respecto.

En caso de admitirse, sosteniendo que puede existir un daño global a los interesados "difusos» o "colectivos" que puede ser económicamente resarcido y que deberá fijar prudencialmente el juez, cabe cuestionarse cómo incide la extensión de los efectos de la cosa juzgada.

De admitirse la reparación en dinero del daño global o difuso, la incidencia de los efectos a otros interesados, seguiría también las reglas que venimos de exponer en casos anteriores. Esto es: si la sentencia dictada en el proceso iniciado por un legitimado en defensa de los intereses difusos obtiene la reparación en dinero del daño global provocado a la sociedad o a una comunidad (por ejemplo, se afectó el patrimonio histórico -imaginemos la destrucción de piezas de museo fundamentales en la historia de un país-), de por sí ese resultado generalmente dará satisfacción a los demás interesados no litigantes (al menos en lo que refiere al perjuicio global), sin necesidad de nuevo proceso.

Como lo hemos indicado antes, el problema fundamental en nuestro sistema jurídico, en caso de que se admitiera la reparación del daño global, es determinar cuál será el destino de la indemnización, lo cual puede llegar a incidir en la admisión o no de la legitimación de determinados sujetos para reclamar la indemnización pecuniaria del daño global.

Aquí también es claro que si el fallo desestimara la demanda por carecer de fundamentos la eficacia de la sentencia será también general, abarcando a los demás interesados, y si el motivo de la desestimación fuera la ausencia o insuficiencia de pruebas, otro legitimado podrá volver a plantear la cuestión en otro proceso. ${ }^{26}$

26 El reclamo de una indemnización por el daño global (para aquellos que lo admiten) no excluye el ejercicio individual de la acción indemnizatoria por quienes particularmente hubieren sufrido un efectivo perjuicio en sus derechos.

Puede darse simultáneamente una ofensa al bien colectivamente considerado (derecho al ambiente, a la salud colectiva, a la información correcta) y lesión a los diversos bienes de que son personalmente titulares los componentes del grupo. Entre el interés difuso, considerado global y el estrictamente individual hay siempre una interrelación permanente, en el sentido de que los individuos particulares que en una situación determinada aparecen vinculados a un interés difuso, son al mismo tiempo titulares de un derecho individual del mismo carácter.

Por ende, los sujetos singularmente damnificados podrían acumular sus pretensiones a la acción colectiva o reclamarla por separado. 
C. Se reclama la reparación de los daños individuales.

Los sujetos que han sufrido un perjuicio individual en sus propios derechos, conservan la facultad de ejercer el reclamo particular, pudiendo, asimismo, optar por la acumulación de su pretensión (la indemnización personal) a la acción promovida para la protección o el resarcimiento del daño colectivo o difuso.

Si hubieran obtenido la reparación acumulando la pretensión individual con la difusa, es claro que una misma sentencia resolverá todas las cuestiones y, obviamente, tendrá contenidos que se extenderán a otros legitimados - los que resuelven sobre las pretensiones de intereses difusos-y otros que solo comprenderán al beneficiario individual, respecto de quien la sentencia obliga le sean reparados los perjuicios personales sufridos.

El problema es más complejo cuando el daño individual se reclama en un proceso independiente.

En este caso, cabe pues analizar cuál es la incidencia del Art. $220^{\circ}$ del CGP.

Para ello, pueden considerarse las siguientes situaciones:

I. Que se pretenda la reparación del daño individual y no haya una sentencia anterior ni sobre intereses difusos o colectivos ni sobre intereses individuales por el mismo acto dañoso.

En este caso, deberá tramitarse un proceso deduciendo la pretensión individual y ninguna incidencia tendrá el Art. $220^{\circ}$ porque no existe sentencia anterior que pueda proyectar sus efectos sobre el proceso que se tramita.

II. Que se pretenda la reparación del daño individual y hubiese una sentencia anterior donde se haya resuelto el reclamo formulado por otro interesado que, si bien refiere solo a la reparación de los daños individuales sufridos por él, tiene repercusión comunitaria y, por ende, se vincula con los intereses difusos o colectivos.

Esta interesante cuestión se planteó en la sentencia dictada por el Juzgado Letrado Civil de $8^{\circ}$ Turno, ${ }^{27}$ por la cual se resolvió el caso de una acción de responsabilidad extracontractual movilizada por los padres de dos menores, actuando por sí y representando a éstos, en base a la contaminación por plomo detectada en ambos niños, que atribuyen a las acti-

27 Sentencia No 1 del 8/2/95 del Juzgado letrado de primera instancia en lo civil de $8^{\circ}$ Turno, dictada por la doctora Ana Lorenzo, en: RUDP 3/95, pp. 321 - 329. 
vidades de una fábrica de baterías demandada, en cuya proximidad habitan. Allí, si bien se trata de un reclamo por un daño directo sufrido por los accionantes, la sentenciante aclara que la actividad industrial derivada del procesamiento de plomo en tanto haya podido originar efluentes o residuos susceptibles de tal perjuicio, involucra un daño al medio ambiente, de repercusión social y comunitaria indiscutible. Se agrega que aunque el reclamo se promueve a título individual, la repercusión comunitaria del daño admite la representación a todo el grupo, dada la acentuación de lo social, en el ámbito aquiliano, incorporando las nociones de responsabilidad grupal y de daño colectivo no receptables en los conceptos tradicionales pero requeridos por la sociedad moderna.

Cabe cuestionarse cuál es la incidencia que tiene, en el nuevo proceso en el cual se reclama la reparación patrimonial individual, el hecho de que en una anterior sentencia, otro legitimado haya formulado un reclamo individual por el mismo acto dañoso, vinculado, por ejemplo con el medio ambiente, o el patrimonio histórico o cultural.

Creemos que pueden postularse distintas soluciones:

a) Sostener que la sentencia dictada en el proceso anterior ninguna incidencia directa tendrá en el nuevo proceso porque en aquel se resolvió una reclamación individual. Ello sin perjuicio de que es frecuente que cuando el reclamo de los perjuicios individuales se vincula con cuestiones que, a su vez, está interesada la comunidad (medio ambiente, consumo, patrimonio histórico o cultural, etc.) la sentencia que acoja la pretensión individual realice consideraciones que pueden ser de utilidad para quien desee iniciar un nuevo proceso reclamando la reparación de los perjuicios individuales o colectivos. En esa hipótesis, podrá mencionarse la sentencia como antecedente - sin que ello implique extender sus efectos a otro proceso- y eventualmente solicitarse el traslado de la prueba (con las consecuencias del Art. $145^{\circ}$ del CGP) al nuevo proceso.

b) Sostener que, en todo caso, puede llegar a extenderse el efecto de la cosa juzgada del primer proceso sobre algún aspecto del nuevo proceso. Así, por ejemplo, si en el primer proceso se reclamare solamente la reparación del daño individual causado a una persona por la acción contaminante de una empresa y se condenare a la empresa por ser contaminante, la cosa juzgada de ese hecho - que la empresa es contaminante-podría extenderse al nuevo proceso en el que otro interesado reclama la reparación de los perjuicios sufridos individualmente. Obviamente, en el nuevo proceso, deberá fundarse y acreditarse la legitimación, el daño y su cuan- 
tía. Si, en cambio, la sentencia del primer proceso fuere desfavorable al actor, deberán realizarse las mismas consideraciones mencionadas en el siguiente punto III. al analizar otra de las hipótesis.

c) Sostener que la solución dependerá de si en el primer proceso, aun cuando se reclamare solo una indemnización por el daño individual, se hubiera o no invocado también el interés difuso o colectivo. En otras palabras, los efectos de la cosa juzgada de algunos aspectos del primer proceso se extenderían al segundo cuando en aquel, el accionante invocó para fundar su reclamo individual la existencia concomitante de un interés difuso o colectivo. Por el contrario, ningún efecto de la cosa juzgada del primer proceso se extenderían al segundo, si en este, el accionante no invoca interés difuso alguno y se basa exclusivamente en su interés individual. El fundamento para postular este criterio podría ubicarse en el Art. $11.3^{\circ} \mathrm{del}$ CGP que exige que para proponer útilmente una pretensión, es necesario invocar el interés de que se trate y ello, eventualmente, podría ser integrante de la causa respecto de la cual tiene que existir identidad para que se configure cosa juzgada.

III. Que se pretenda la reparación del daño individual y haya una sentencia anterior sobre intereses difusos o colectivos por el mismo acto dañoso.

En este caso si bien, como habremos de verlo, la sentencia anterior desplegará sus efectos sobre el reclamante, es indispensable tramitar un nuevo proceso cuyo objeto probablemente sea más reducido en virtud, precisamente, de la extensión de los efectos.

Imaginemos que primero un interesado invocando intereses difusos tramita con éxito un proceso ordinario reclamando el cese de la acción contaminante de una empresa y, a su vez, la reparación de los perjuicios colectivos y/o individuales sufridos por dicha acción.

Luego, otro interesado, desea reclamar contra la misma empresa la reparación de los perjuicios individualmente sufridos por la misma acción contaminante. Para ello, deberá necesariamente tramitar un nuevo proceso.

Se discute cuál es la estructura que tendrá este segundo proceso, existiendo dos posiciones: una que opina que procede la vía ordinari $a^{28} \mathrm{y}$ otra

28 En esta posición se han pronunciado E. Véscovi y colaboradores, Código [...], op. cit., t. 6. comentarios al Art. $220^{\circ}$ y S. Pereira Campos, Intereses difusos y efectos[...], op.cit., p. 340 y ss. e Intereses difusos y colectivos [...], op. cit. Fundan su opinión estos autores en que en el nuevo proceso no solo deberá debatirse y probarse la entidad y monto 
que postula la vía incidental de liquidación de los daños. ${ }^{29}$

El objeto de este segundo proceso será más limitado porque el hecho de que la empresa demandada fue contaminante será cosa juzgada que del otro proceso se extiende a este, debiendo limitarse el reclamante en este proceso a probar que queda alcanzado en la legitimación que amerite la reparación y, obviamente que fue alcanzado por el daño y el monto del mismo.

En otras palabras, en el juicio posterior el interesado no interviniente en el proceso anterior, podrá hacer valer en su beneficio, la cosa juzgada del juicio anterior, en todo lo que no sea específico; por ejemplo, el demandado no podrá discutir el carácter masivo de la polución declarado en el juicio anterior; el nuevo actor deberá demostrar su pertenencia al grupo y la medida de su perjuicio.

Puede suceder también que en el primer proceso tramitado por un legitimado en defensa de intereses difusos, la sentencia haya sido desestimatoria. En este caso, si otro legitimado reclamara en un nuevo proceso los daños personales sufridos (por ejemplo por la acción contaminante de una empresa), los efectos de la sentencia desestimatoria del proceso anterior se extenderán al nuevo o no dependiendo del motivo de la desestimación:

a) Si el rechazo se debió a la ausencia o insuficiencia de prueba, ninguna incidencia tendrá ello en el nuevo proceso.

b) Si el rechazo se debió a la falta de fundamentos de la demanda, creemos que debe analizarse con cautela en qué aspectos la sentencia dictada en el proceso anterior considera que la pretensión es infundada.

Así, por ejemplo, si la sentencia declaró infundado que pueda verificarse un acto dañoso (la contaminación) por tal o cual actividad de la empresa demandada, tal circunstancia proyectará sus efectos sobre el nue-

de los daños, como sucede en el proceso incidental de liquidación de daños, sino también si el reclamante en este proceso queda alcanzado en la legitimación que amerite la reparación y, obviamente, que fuera alcanzado por el daño.

29 A. Landoni, La tutela de los derechos del consumidor [...], p. 307, donde señalamos: «En el sistema actualmente vigente del CGP si la sentencia fuese favorable a los consumidores, no se plantearán mayores problemas. En efecto, el fallo determinará que en la especie existió responsabilidad y condenará en forma genérica al proveedor a indemnizar los perjuicios que se hubieren causado, los que se determinarán y probarán en la vía incidental correspondiente (CGP arts. $378^{\circ} .3$ y $321^{\circ}$ )".

"Quiere decir que la sentencia tendrá efecto general, pero cada consumidor deberá alegar y probar en vía incidental los perjuicios que efectivamente ha sufrido". 
vo proceso en que se reclama el daño individual eventualmente causado por dicha actividad. Por ende, la sentencia del nuevo proceso desestimará también la demanda alegando cosa juzgada de un proceso anterior cuyos efectos se extendieron al nuevo.

$\mathrm{Si}$, en cambio, la sentencia del primer proceso admite que existió una acción contaminante de la empresa pero desestima la pretensión porque carece de fundamento que el legitimado pueda haber sufrido un perjuicio derivado de tal actividad (falta de legitimación sustantiva porque, por ejemplo, quien vive a determinada distancia de la empresa no puede sufrir los perjuicios de la acción contaminante en cuestión), ello no inhibirá que otro legitimado (que vive más cerca de la zona afectada) en un nuevo proceso, reclame con éxito los daños y perjuicios derivados de la misma acción contaminante. Contará además con la ventaja de que será cosa juzgada que existió una acción contaminante.

Para que este complejo sistema de extensión de efectos que venimos de describir pueda tener adecuado funcionamiento, es esencial que en la sentencia dictada sobre intereses difusos el juez establezca claramente cuál es el grupo, comunidad, zona o sector alcanzado por la decisión que, eventualmente, podrá invocar en otro proceso el amparo de la sentencia dictada anteriormente.

Debe tenerse en cuenta que las soluciones actuales del CGP fundamentalmente en lo que tiene que ver con la cosa juzgada no evitará en algunos casos los riesgos de actuaciones colusivas entre organizaciones supuestamente representativas de los intereses difusos y/o colectivos y demandados (Ej: proveedores inescrupulosos). En muchos casos puede resultar complejo para nuestros jueces apreciar si la asociación en cuestión, que supuestamente representa intereses difusos, tiene efectivamente la representatividad adecuada y si ella puede garantizar la correcta defensa del interés comprometido.

La solución del Art. $220^{\circ}$ del CGP otorgando a la sentencia eficacia general —salvo si fuere absolutoria por ausencia de pruebas- puede dejar en algunos casos sin protección al particular interesado que con total desconocimiento del proceso se verá afectado por él. ${ }^{30}$

30 En la búsqueda de posibles soluciones para este problema y utilizando para ello los textos vigentes, hemos indicado que la jurisprudencia podría sostener:

A) Que las expresiones del legislador acerca de que la sentencia tendrá eficacia general salvo si fuere absolutoria por ausencia de pruebas comprende, en la exclusión, tanto aquellas 
Finalmente cabe destacar que son aplicables, además, las consecuencias más corrientes de derecho procesal: la acumulación de autos, la integración de la parte mediante citación de las no intervinientes, la acción declarativa negativa genérica del posible contaminador o discriminador, etc. ${ }^{31}$

\subsection{Conveniencia de realizar ajustes en las normas legales sobre cosa juzgada en materia de intereses difusos y colectivos}

La solución del CGP uruguayo con relación a los efectos de la cosa juzgada en procesos promovidos en re-presentación de intereses difusos o colectivos (Art. $220^{\circ}$ ) significó un gran avance. No obstante, la misma podría ser perfeccionada siguiendo en general los lineamientos del Código de defensa del consumidor brasileño, con los ajustes necesarios. ${ }^{32}$

Nótese que nuestro legislador no ha distinguido, como con acierto lo hizo el brasileño, entre intereses o derechos difusos, intereses o derechos colectivos e intereses o derechos individuales homogéneos. Ello permitiría establecer, además, la posibilidad de distintos grados de eficacia para las sentencias dictadas en dichos procesos.

Quizá la escasa jurisprudencia nacional sobre el tema no haya puesto aún de relieve los problemas prácticos que pueden plantearse con una regulación tan genérica de la cuestión como la que tiene Uruguay.

hipótesis en que no existió ninguna prueba, como aquellas otras, en las que la prueba aportada no fue lo suficientemente convincente como para obtener una sentencia favorable. Si tal tesis prosperase, indudablemente los particulares interesados, pese a que la acción colectiva hubiese sido desestimada, podrian deducir sus acciones en forma independiente, sin que frente a ellas se les pudiese oponer válidamente la excepción de cosa juzgada.

B) Una segunda solución, podría basarse en que la norma del Art. $220^{\circ}$ no alcanzaría a los terceros que no han tenido conocimiento judicial del pleito, fundándose para ello en que no se han respetado en su caso las garantías del contradictorio, tomando además en cuenta las previsiones de los arts. $218^{\circ} .3$ y $14^{\circ}$ del CGP. A este esbozo de solución se le podría, a su vez, oponer la crítica de que si esos supuestos terceros estuvieron adecuadamente representados, no serían propiamente terceros y por ende estarían alcanzados por la eficacia subjetiva de la cosa juzgada, ya que no podrían válidamente alegar que no se les otorgaron las garantías del contradictorio y de que no tuvieron conocimiento del proceso (A. Landoni, "La tutela de los derechos del consumidor [...]", pp. 307 - 309).

31 Cf. D. Barrios de Angelis, «Introducción [...]", pp. 123-126.

32 Cf. A. Landoni, La tutela de los derechos del consumidor [...], p. 302 y ss. 
VIII. La relatividad de la cosa juzgada. Su revisión

\subsection{Las líneas de la doctrina}

Los autores clásicos, entre otros: Chiovenda, Carnelutti, Calamandrei, Couture, Goldschmidt, Schonke y Rosenberg, así como la generación que nos precedió: Gelsi Bidart, Devis Echandía, Véscovi, sostuvieron la posibilidad de revisión de la cosa juzgada en aquellos casos de excepción donde se dieran situaciones de dolo, fraude, colusión o indefensión de las partes o de los terceros involucrados.

La doctrina más reciente también se ha inclinado en la misma línea, y en tal sentido parece oportuno citar los trabajos de Hitters, Revisión de la cosa juzgada, Librería Editora Platense, La Plata, 1977, otro estudio posterior del mismo autor, titulado «Revisión de la cosa juzgada. Su estado actual", publicado en: RUDP 1/1999, pp. 9-20; Roberto Berizonce, "Cosa juzgada fraudulenta y acción de nulidad", en: JUS, Revista Jurídica de la Provincia de Buenos Aires, Librería Editora Platense SRL, V.10, p. 78; Véscovi y colaboradores, en: Código general del proceso uruguayo anotado, Cándido Dinamarco en sus diversas publicaciones y más recientemente en su estudio "Relativizar a coisa julgada material", presentado en el Congreso Brasileño de Derecho Procesal que tuvo lugar en la ciudad de Fortaleza en agosto del 2001, y el del profesor uruguayo doctor Santiago Pereira Campos, «El recurso de revisión y la acción revocatoria en el Código General del Proceso", publicado en la RUDP 3/1990, p. 456 y ss.

También hemos acompañado la referida corriente de pensamiento en nuestro trabajo sobre "El recurso de revisión» en: Curso sobre el Código General del Proceso, Tomo II, 1989, editado por Fundación de Cultura Universitaria.

\subsection{El Derecho iberoamericano}

Dada la necesaria brevedad que este estudio debe tener, solo procederemos a reseñar las disposiciones legales vinculadas al tema de España, Brasil, Colombia, Argentina y las soluciones del proyecto de código modelo y del código general del proceso de Uruguay. 


\section{A) España:}

La nueva Ley de Enjuiciamiento Civil 1/2000, del 7 de enero del 2000, prevé dos vías de impugnación de las sentencias firmes: la acción rescisoria planteada por el demandado rebelde y la acción de revisión.

La acción rescisoria planteada por el demandado rebelde.

- Causales.

El Art. $501^{\circ}$ de la nueva LEC establece que:

"Los demandados que hayan permanecido constantemente en rebeldía podrán pretender del tribunal que la hubiere dictado, la rescisión de la sentencia firme en los casos siguientes:

$\left.1^{\circ}\right)$ De fuerza mayor ininterrumpida que impidió al rebelde comparecer en todo momento, aunque haya tenido conocimiento del pleito por haber sido citado o emplazado en forma.

$\left.2^{\circ}\right)$ De desconocimiento de la demanda y del pleito, cuando la citación o emplazamiento se hubieren practicado por cédula a tenor del Art. $161^{\circ}$, pero ésta no hubiese llegado a poder del demandado rebelde por causa que no le sea imputable.

$3^{\circ}$ ) De desconocimiento de la demanda y del pleito cuando el demandado rebelde haya sido citado o emplazado por edictos y haya estado ausente del lugar en que se haya seguido el proceso y de cualquier otro lugar del Estado o de la Comunidad Autónoma, en cuyos Boletines Oficiales se hubiesen publicado aquellos».

\section{- Caducidad.}

La ley prevé diversos plazos de caducidad de la acción de rescisión (Art.5020), a saber:

$\left.1^{\circ}\right)$ de veinte días a partir de la notificación de la sentencia firme, si dicha notificación se hubiere practicado personalmente;

$2^{\circ}$ ) de cuatro meses, a partir de la publicación del edicto de notificación de la sentencia firme, si ésta no se notificó personalmente.

Estos plazos podrán prolongarse si subsistiera la fuerza mayor que hubiera impedido al rebelde la comparecencia, pero sin que en ningún caso quepa ejercitar la acción de rescisión una vez transcurridos dieciséis meses desde la notificación de la sentencia. 
- Disposiciones varias.

Se prevé la eventual suspensión de la ejecución dando garantías suficientes para responder por los daños y perjuicios (arts. $504^{\circ}$ y $566^{\circ}$ ), la sustanciación del procedimiento (Art. 5070) y se dispone que la inactividad de quien pretende la rescisión hará que se dicte sentencia en los mismos términos que aquella cuya rescisión se pretendía (Art. 508\%). ${ }^{33}$

- La acción de revisión de sentencias firmes.

- Motivos de la revisión

El Art. $510^{\circ}$ de la LEC establece como causales las siguientes:

$\left.1^{\circ}\right)$ Si después de pronunciada, se recobraren y obtuvieren documentos decisivos, de los que no se hubiera podido disponer por fuerza mayor o por obra de la parte en cuyo favor se hubiere dictado.

$\left.2^{\circ}\right)$ Si hubiere recaído en virtud de documentos que al tiempo de dictarse ignoraba una de las partes haber sido declarados falsos en un proceso penal, o cuya falsedad se declarare después penalmente.

$\left.3^{\circ}\right)$ Si hubiere recaído en virtud de prueba testifical o pericial, y los testigos o los peritos hubieren sido condenados por falso testimonio dado en las declaraciones que sirvieron de fundamento a la sentencia.

$\left.4^{\circ}\right) \mathrm{Si}$ se hubiere ganado injustamente en virtud de cohecho, violencia o maquinación fraudulenta.

- Legitimación activa:

El Art. $511^{\circ}$ la limita a «[...] quien hubiere sido parte perjudicada por la sentencia firme impugnada".

En tal sentido creo que es más adecuada la solución del Art. $284^{\circ} \mathrm{del}$ C.G.P. uruguayo (C. Modelo 254) que extiende dicha legitimación a los sucesores o causahabientes, a los terceros en determinadas hipótesis y al Ministerio Público cuando los hechos invocados afectaren la causa pública. - Plazo de interposición.

De acuerdo con el Art. $512^{\circ}$, en ningún caso podrá solicitarse la revisión después de transcurridos cinco años desde la fecha de la publicación de la sentencia que se pretende impugnar. Se rechazará toda solicitud de revisión que se presente pasado este plazo.

Dentro del plazo señalado en el apartado anterior, se podrá solicitar la revisión siempre que no hayan transcurridos tres meses desde el día en que

33 Considero que existe error en la redacción de la norma pues refiere «[...] se dictará nueva sentencia en los mismos términos que la rescindidan, cuando - en nuestra opinión- dicha sentencia aún no estaba rescindida. 
se descubrieren los documentos decisivos, el cohecho, la violencia o el fraude, o en que se hubiere reconocido o declarado la falsedad.

- Depósito previo.

La ley exige un depósito previo de 50.000 pesetas para poder interponer la demanda de revisión (Art. 513\%), suma que será devuelta si el tribunal estimare la demanda de revisión.

- Trámite:

La LEC lo regula en el Art. $514^{\circ}$ estableciéndose que el Ministerio fiscal deberá informar sobre la revisión antes de que se dicte sentencia y si se plantearen cuestiones prejudiciales penales durante la tramitación de la revisión no operará el plazo absoluto de caducidad de cinco años previsto en el apartado $1^{\circ} \mathrm{del}$ Art. $512^{\circ}$

- Decisión (Art. 516\%)

Si el tribunal estimare procedente la revisión solicitada, lo declarará así y rescindirá la sentencia impugnada.

A continuación, mandará expedir certificación del fallo y devolverá los autos al tribunal del que procedan para que las partes usen de su derecho, según les convenga en el juicio correspondiente.

En este juicio, habrán de tomarse como base y no podrán discutirse las declaraciones hechas en la sentencia de revisión.

Si el tribunal desestimare la revisión solicitada, se condenará en costas al demandante y perderá el depósito que hubiere realizado.

Contra la sentencia que dicte el tribunal de revisión no habrá recurso alguno.

B) Brasil:

- Introducción:

El Código del Proceso Civil brasileño en el Capítulo IV del Título IX regula «la acción rescisoria».

- Causales de la acción rescisoria.

Establece en el Art. 485\%:

"La sentencia de mérito con autoridad de cosa juzgada, puede ser rescindida cuando:

I) se verificase que fue dada con prevaricación, concusión o corrupción del juez;

II) que fue proferida por juez impedido o absolutamente incompetente; 
III) resultare del dolo de la parte vencedora en detrimento de la parte vencida, o de colusión entre las partes, con el fin de defraudar la ley; IV) ofensa a la cosa juzgada;

V) viole una disposición literal de la ley;

VI) se funde en prueba, cuya falsedad haya sido constatada en proceso criminal o sea probada en la propia acción rescisoria;

VII) si después de la sentencia, el actor obtuviere un documento nuevo, cuya existencia ignoraba, o del cual no pudo hacer uso, que por sí solo era capaz de asegurarle un pronunciamiento favorable;

VIII) si hubiere fundamento para invalidar la confesión, el desistimiento o la transacción, en que se basó la sentencia;

IX) si está fundada en error de hecho, resultante de los actos o de los documentos de la causa.

1 - Existe error, cuando la sentencia admitiese un hecho inexistente, o cuando considerase inexistente un hecho efectivamente ocurrido.

2- Es indispensable, en un caso como en el otro, que no haya habido controversia, ni pronunciamiento judicial sobre el hecho".

\section{- Legitimación:}

Conforme al Art. $487^{\circ}$ del Código del Proceso Civil están legitimados para proponer la acción:

A) quien fuera parte en el proceso o su sucesor a título universal o singular;

B) el tercero jurídicamente interesado;

C) el Ministerio Público en las siguientes circunstancias:

- si no fue oído en el proceso cuando era obligatoria su intervención;

- cuando la sentencia es el efecto de la colusión de las partes en fraude a la ley.

- Caución:

Quien deduce la pretensión rescisoria debe depositar el 5\% del valor de la causa, a título de multa para el caso de que la acción sea, por unanimidad de votos declarada inadmisible o improcedente (Art. $488^{\circ}$ II).

- No suspensión de la ejecución.

El Art. $489^{\circ}$ expresamente establece que la acción rescisoria no suspende la ejecución de la sentencia.

- Caducidad.

El derecho a proponer la acción rescisoria - conforme al Art. $495^{\circ}-$ se extingue a los dos años desde que la sentencia adquirió la autoridad de la cosa juzgada. 
Cándido Dinamarco, ${ }^{34}$ comentando el derecho brasileño y citando a Pontes de Miranda, indicaba que se ha llevado demasiado lejos la noción de cosa juzgada y considera que es necesario relativizarla tomando en cuenta los siguientes elementos:

I) el principio de razonabilidad y de proporcionalidad como condicionantes de la inmunización de las decisiones que han adquirido la autoridad de la cosa juzgada material;

II) la moralidad administrativa como valor constitucionalmente proclamado y cuya efectivización obsta a esa autoridad en relación a fallos absurdamente lesivos al Estado;

III) el imperativo constitucional del justo valor de la indemnización en las expropiaciones inmobiliarias, el cual es transgredido tanto si el ente público es llamado a pagar demás, como cuando es autorizado a pagar menos que lo correcto;

IV) el celo ciudadano por los derechos del hombre, también existente en la Constitución brasileña, como impedimento a tolerar en forma perenne decisiones inaceptables en detrimento de los particulares;

V) el fraude y el error grosero como factores que contaminando el resultado del proceso autorizan la revisión de la cosa juzgada;

VI) la garantía constitucional del medio ambiente ecológicamente equilibrado, que no debe quedar fuera de la consideración en la sentencia pasada en autoridad de cosa juzgada;

VII) la garantía constitucional del acceso a un orden jurídico justo, que repele la eternización de fallos que en forma aberrante discrepan con los dictados de la justicia y la equidad;

VIII) el carácter excepcional de la disposición a flexibilizar la autoridad de la cosa juzgada, sin la cual el sistema procesal perdería utilidad y confiabilidad, en razón de la inseguridad que ello generaría.

En cuanto a los remedios procesales a utilizar, señala Dinamarco ${ }^{35}$ que la casuística demuestra que los tribunales brasileños no han sido particularmente exigentes en cuanto a la elección de la vía procesal adecuada para el apartamiento de la cosa juzgada en los casos en examen.

Así, en caso de sentencia proferida sin la citación regular del reo, el Supremo tribunal federal admitió que ese vicio puede ser examinado en

34 Cándido Rangel Dinamarco, "Relativizar a coisa julgada material", ponencia presentada al Congreso Brasileño de Derecho Procesal, en agosto de 2001, op, cit., realizado en Fortaleza (Brasil), p. 8.

35 Cándido Dinamarco, «Relativizar [...]”, op cit., p. 15. 
la acción rescisoria, mediante oposición a la ejecución si se tratase de sentencia condenatoria o aún a través de una "acción declaratoria de nulidad absoluta e insanable de la sentencia».

Para la hipótesis de desobediencia a las reglas específicas del litisconsorcio necesario - unitario, el autor que estamos citando viene sustentando una amplia apertura de las vías procesales, correspondiendo al interesado optar por la que más le convenga: sea la acción rescisoria, el mandado de segurança o la acción declarativa de ineficacia.

La acción autónoma a la que alude el Supremo tribunal federal es la sugerida por Calamandrei para quien:

«[...] el único medio adecuado contra la sentencia nula será la acción declarativa negativa de certeza, mediante la cual, sin aportar modificación alguna al mundo jurídico, se declara el carácter negativo que el contenido de la sentencia trajo consigo desde el momento de su concepción".

En lo referente a la acción rescisoria, Dinamarco considera que debe ser redimensionada en cuanto a los límites de su admisibilidad.

Expresa que es tradicionalmente indicada como un remedio rigurosamente extraordinario de ir contra la cosa juzgada material, reputada ésta como un valor a ser preservado a toda costa y sujeta a cuestionamientos solo en casos verdaderamente extraordinarios.

Las hipótesis de su admisibilidad establecidas en el Art. $485^{\circ}$ son «numerus clausus» y los tribunales brasileños siempre se esmeran en restringir la interpretación de dichas causales.

Dinamarco señala que "[...] es imperioso abrir los espíritus para la interpretación de los incisos del Art. $485^{\circ}$ del Código del Proceso Civil, de modo de permitir el análisis de las sentencias bajo el prisma de la constitucionalidad de las decisiones- o sea, se impone la relativa y prudente flexibilización de las hipótesis de admisibilidad de la acción rescisoria, para que ella sirva de remedio contra las malas decisiones, flagrantemente inconstitucionales, o fundadas en prueba falsa, en el fraude o en el dolo de una de las partes en detrimento de otra, etc. [...].«La línea propuesta no va en el sentido insensato de minar imprudentemente la autoridad de la cosa juzgada o transgredir sistemáticamente lo que a su respecto asegura la Constitución 
Federal y dispone la ley. Se propone apenas un trato extraordinario destinado a situaciones fuera de lo común, con el objetivo de apartar fallos absurdos, injusticias flagrantes, fraudes o infracciones a la Constitución, con la conciencia de que las providencias destinadas a ese objetivo deben ser tan excepcionales cuanto es la ocurrencia de esos graves inconvenientes. No me mueve la intención de proponer una insensata inversión, para que la garantía de la cosa juzgada pasase a operar en casos raros y su infracción se tornase en regla general".

\section{C) Colombia}

El Código de Procedimiento Civil ${ }^{36}$ dentro del Título XVI «Efectos y ejecución de las providencias" regula en el Capítulo VI arts. $379^{\circ}$ y ss. el recurso de revisión.

- Naturaleza del recurso de revisión.

Conforme al Art. $379^{\circ}$ es un recurso extraordinario que procede contra las sentencias ejecutadas por la Corte Suprema, los tribunales superiores, los jueces de circuito, municipales y de menores.

- Causales.

De acuerdo al Art. $380^{\circ}$, son las siguientes:

1. Haberse encontrado después de pronunciada la sentencia documentos que habrían variado la decisión contenida en ella, y que el recurrente no pudo aportarlos al proceso por fuerza mayor o caso fortuito o por obra de la parte contraria.

2. Haberse declarado falsos por la justicia penal documentos que fueren decisivos para el pronunciamiento de la sentencia recurrida.

3. Haberse basado la sentencia en declaraciones de personas que fueron condenadas por falso testimonio en razón de ellas.

4. Haberse dictado la sentencia con base en dictamen de peritos condenados penalmente por ilícitos cometidos en la producción de dicha prueba.

5. Haberse dictado sentencia penal que declare que hubo violencia o cohecho en el pronunciamiento de la sentencia recurrida.

6. Haber existido colusión u otra maniobra fraudulenta de las partes en el proceso en que se dictó la sentencia, aunque no haya sido objeto de investigación penal, siempre que haya causado perjuicios al recurrente.

36 Extraído de Internet en: httpllwww.leyesnet.com/ ver Códigos. 
7. Estar el recurrente en alguno de los casos de indebida representación o falta de notificación o emplazamiento contemplados en el Art. $140^{\circ}$, siempre que no haya saneado la nulidad.

8. Existir nulidad originaria en la sentencia que puso fin al proceso y que no era susceptible de recurso.

9. Ser la sentencia contraria a otra anterior que constituya cosa juzgada entre las partes del proceso en que aquella fue dictada, siempre que el recurrente no hubiera podido alegar la excepción en el segundo proceso por habérsele designado curador ad litem y haber ignorado la existencia de dicho proceso. Sin embargo, no habrá lugar a revisión cuando en el segundo proceso se propuso la excepción de cosa juzgada y fue rechazada. - Término para interponer el recurso.

En general (Art. $381^{\circ}$ ) se podrá interponer dentro de los dos años siguientes a la ejecutoria de la respectiva sentencia.

Cuando se alegue la causa prevista en el Art. $380^{\circ} \mathrm{No} 7$-indebida representación o falta de notificación o emplazamiento- los dos años comenzarán a correr desde el día en que la parte perjudicada por la sentencia o su representante hayan tenido conocimiento de ella, con límite máximo de cinco años.

En los casos contemplados en los numerales 2 (documento falso), 3 (testigo falso), 4 (perito condenado penalmente) y 5 (violencia o cohecho en la sentencia), deberá interponerse el recurso dentro del término de dos años, pero si el proceso penal no hubiere terminado, se suspenderá la sentencia de revisión hasta cuando se produzca la ejecutoria del fallo penal y se presente la copia respectiva.

Esta suspensión no podrá exceder de dos años.

- Caución (Art. 3830).

Si se declara admisible el recurso se fija la caución que el recurrente deberá constituir, para garantizar los perjuicios que pueda causar a quienes fueron partes en el proceso en que se dictó la sentencia, las costas, las multas y los frutos civiles y naturales que se estén debiendo.

- Sentencia.

Caben varias posibilidades:

* Si la Corte o Tribunal encuentra fundada alguna de las causales de los numerales 1 a 609 del Art. $380^{\circ}$, invalidará la sentencia revisada y dictará la que por derecho corresponde.

* Si halla fundada la del numeral 8 (nulidad originada en la propia sentencia y que no era recurrible), declarará sin valor la sentencia y devol- 
verá el proceso al tribunal o juzgado de origen para que la dicte de nuevo.

* Si encuentra fundada la del numeral 7 (indebida representación o falta de notificación o emplazamiento), declarará la nulidad de lo actuado en el proceso que dio lugar a la revisión.

En la sentencia que invalide la revisada se resolverá sobre las restituciones, cancelaciones, perjuicios, frutos, mejoras, deterioros y demás consecuencias de dicha invalidación.

Si se declara infundado el recurso, se condenará en costas y perjuicios al recurrente y para su pago se hará efectiva la caución prestada.

\section{D)Argentina}

El recurso de revisión, según expresa Hitters, ${ }^{37}$ tuvo una efímera vigencia en la Ley № 27 del año 1862 que le daba cabida para los casos de competencia originaria de la Corte Federal. A su vez la Ley No 50 de 1863 lo mantuvo en condiciones similares, lo mismo que la Ley No4055 y la Ley No 13.998.

El recurso de revisión desaparece sin explicación en el Código Procesal Civil y Comercial de la Nación, pudiéndose inferir: o que el legislador ni siquiera lo tuvo en cuenta, ya sea porque estimó que estos engranajes habían quedado definitivamente abandonados en el derecho argentino; o bien - que es lo más probable - no le pareció necesario hacer aclaración alguna en la exposición de motivos habida cuenta de que la revisión se había afianzado a través de la acción autónoma.

Recordemos que Argentina es un país federal y que algunas provincias (Córdoba, La Rioja, Mendoza, San Juan, Corrientes, Chaco y Tierra del Fuego) han consagrado el recurso de revisión, estableciendo causales taxativas, que generalmente se ventilan ante el tribunal superior local y se fijan plazos perentorios para su interposición que varían según los diversos Códigos.

- La acción autónoma de revisión.

Señala Hitters, ${ }^{38}$ que por los años cuarenta se presentaron los primeros antecedentes jurisprudenciales donde se le dio vía libre a la acción autónoma, criterio que se ha ido afirmando a través del tiempo.

37Juan C Hitters, Revisión de la cosa juzgada, Librería Editora Platense SRL, La Plata, 1977; del mismo autor, «Revisión de la cosa juzgada. Su estado actual», en: RUDP 1/ 1999, pp. 9-20.

38 Juan C. Hitters, Revisión de la cosa juzgada. Su estado actual, op.cit., p. 16. 
Sintetizando la doctrina legal fijada sobre este tema por la Corte Suprema de Justicia de la Nación Argentina, indicó que:

1) La cosa juzgada no es absoluta (Tibold, Campbell Dadvison y Atlántida).

2) La firmeza de la res judicata debe estar condicionada a la inexistencia de vicios de la voluntad tanto de las partes como del juzgador (Tibold, Campbell Dadvison y Bemberg).

3) La seguridad jurídica debe ceder a la razón de justicia (Tibold, Campbell Dadvison, Atlántida y Bemberg).

4) La estafa procesal no puede ser convalidada por los órganos jurisdiccionales (Tibold y Atlántida).

5) Para la configuración de la cosa juzgada es necesaria la existencia de un juicio regular (debido proceso), fallado libremente por los jueces (Campbell Dadvison y Bemberg).

6) La falta de un procedimiento ritual específico no es óbice para que el órgano jurisdiccional disponga la revisión (Campbell Dadvison) 7) Para comprobar los vicios (sustanciales) no es el recurso extraordinario la vía idónea, sino que es necesario un proceso de conocimiento donde se puedan debatir ampliamente los elementos fácticos que den viabilidad a la revisión (Campbell Dadvison).

Corresponde destacar que Hitters cita ${ }^{39}$ un reciente pronunciamiento del Superior tribunal de justicia de la provincia de Córdoba que admitió la revisión de la cosa juzgada en base a motivos o causales no contemplados en el ordenamiento adjetivo de dicha provincia que regula expresamente el recurso de revisión.

Se dijo en dicha sentencia, que nada obsta a la procedencia de la pretensión autónoma, la circunstancia que el recurso de revisión no prevea tal posibilidad, ya que la primera es de naturaleza sustancial y el segundo de esencia ritual; por lo tanto la acción puede tener cabida fuera del marco taxativo previsto en el carril recursivo.

Hitters, por último, realiza dos advertencias: la primera de que solo puede haber revocación si hubo vicios trascendentes no originados o no advertidos por las partes antes de que el fallo quede firme, y la segunda, de que la apertura debe interpretarse con un criterio notoriamente restringi-

39 Juan C. Hitters, Revisión[...], op, cit., p. 18, nota 54. 
do, pues de lo contrario se podría anular cualquier sentencia injusta en todo tiempo y ello sería totalmente inconveniente, ya que la seguridad jurídica sigue siendo un pilar fundamental de todo estado de derecho.

\subsection{Las soluciones del Proyecto de código modelo para Iberoamérica y del C.G.P. uruguayo}

\subsubsection{Introducción}

La revisión de la cosa juzgada en casos de dolo, fraude, colusión o indefensión había sido aceptada en el proceso civil uruguayo, tanto por la doctrina como por la jurisprudencia, aun antes de que se consagrase el recurso de revisión en un texto legal, circunstancia que ocurrió posteriormente al entrar en vigencia el Código General del Proceso en noviembre de 1989.

Resulta oportuno recordar que Couture ${ }^{40}$ señalaba que los actos procesales y aun la sentencia pasada en autoridad de cosa juzgada pueden ser consecuencia del fraude, y definía a este ${ }^{41}$ como la "calificación jurídica de la conducta, consistente en una maquinación o subterfugio insidioso tendiente a la obtención de un provecho ilícito".

Unas veces, ese fraude - decía - va dirigido de un litigante contra otro; otras veces, el fraude va dirigido de ambos litigantes hacia un tercero; otras, del juez a una parte o a ambas; y otras, de las partes (y eventualmente del juez) hacia el orden jurídico (fraus legi).

Con respecto a los fines de la revocación de los actos fraudulentos señalaba que es una solución ligada inseparablemente a sus fines propios. Esos fines son, en lo esencial, reparar el daño causado por el dolo o fraude, ya que no se trata de anular por anular, ni de revocar por revocar, sino que se anula o revoca para evitar los perjuicios causados. En principio, donde no exista perjuicio, no habrá revocación.

Couture concluía afirmando la tesis — reiteradamente aplicada por nuestra jurisprudencia - de la admisibilidad de una acción autónoma revocatoria de la cosa juzgada fraudulenta, aún en aquellas legislaciones que carecieran de previsiones especiales, como era la situación de nuestro

40 Eduardo J. Couture, La acción revocatoria de la cosa juzgada fraudulenta, RDJA, Tomo 38, p. 13 y ss. y Tomo III de sus Estudios, pp. 387-416.

41 Eduardo Couture, Vocabulario Jurídico, Ed. Depalma, 1983, voz: fraude, p. 295. 
país hasta el establecimiento del recurso de revisión en materia civil por el Código general del proceso.

Gelsi Bidart ${ }^{42}$ también admitía la procedencia de la acción de nulidad desarrollada en un proceso especial.

Estimaba dicho autor que la resistencia a acoger la impugnación de la cosa juzgada mediante una acción autónoma se basaba en dos razones fundamentales: $1^{\circ}$ ) inexistencia de un texto habilitante; $2^{\circ}$ ) el ataque a la firmeza de la cosa juzgada.

Con respecto al primer punto señalaba que al:

«[...] Derecho Procesal en sí, repugna la indefensión, es decir, que alguien asistido de razones contra lo que puede perjudicarlo, se encuentre inhibido de expresarlo por carecer de medios procesales al efecto; la protección de la justicia y de la libertad para la cual se forma el proceso quedaría desvirtuada».

Y se inclinaba por la vía del juicio ordinario como la adecuada para tramitar acciones como la autónoma que no tenían procedimiento previsto.

Con relación a la cosa juzgada indicaba: I) que ésta para ser tal debe de haber recaído en un proceso válido y eficaz, y este es su primer límite.

La acción autónoma de nulidad no significa ataque a la cosa juzgada, sino que en aquellas hipótesis en que se configure la inexistencia del acto o se haya producido una nulidad absoluta en el proceso, la acción de nulidad lo único que hace es poner en claro lo que ha ocurrido. La verdadera situación ha sido encubierta por una apariencia engañosa (cosa juzgada aparente) sin realidad jurídica y por ende, no existe en la especie verdadera cosa juzgada, pues ésta realmente no se ha configurado.

En esta hipótesis - como lo ha señalado la jurisprudencia- en caso de darse la nulidad por vicio en el emplazamiento, ${ }^{43}$ bastaría acreditar el hecho del no emplazamiento, es decir, la constatación objetiva de que el reo no fue debidamente llamado al juicio, sin que se requiera investigación alguna sobre el elemento subjetivo que conduce a ese resultado.

En este supuesto bastaría eliminar de la cosa juzgada el juicio regular o

42 Adolfo Gelsi Bidart, De las nulidades en los actos procesales, Biblioteca de Publicaciones Oficiales de la Facultad de Derecho y Ciencias Sociales de la Universidad de Montevideo, (1949), Uruguay, pp. 351-360.

43 LJU, Tomo 75, Caso № 8614, p. 225. 
válido para que ella desaparezca, descartado el soporte de la cosa juzgada, ésta también se aniquila. No importa que el actor que gestionó mal el emplazamiento del reo (configurándose su no emplazamiento) haya sido diligente o haya procedido con culpa o con intención aviesa, el no llamamiento regular del reo al juicio conduce siempre a la nulidad porque solo hay una apariencia de proceso.

II) dentro de la hipótesis anterior Gelsi incluye la no citación al condómino dada su condición de litisconsorte necesario.

III) que existe un tercer límite a la cosa juzgada que se produce cuando hay fraude procesal.

El concepto de fraude procesal ha sido exhaustivamente analizado por Gelsi Bidart, ${ }^{44}$ quien lo define en estos términos: «El fraude procesal consiste en la actividad (uno o varios actos) de uno o más de los sujetos procesales (fraude uni o bilateral), tendiente a lograr (causa final mediata), a través de la actividad procesal normal (específicamente: mediante actividad válida salvo la causa final indicada) pero de manera insidiosa, maquinada y, por ende, indirecta, un daño ilícito que en definitiva se produzca, en perjuicio de un sujeto pasivo que normalmente será tercero al proceso, pero que puede ser la contraparte y generalmente también el Juez, en tanto se haga cómplice involuntario del fraude».

La jurisprudencia ${ }^{45}$ citando a Gelsi ha puesto de relieve que la finalidad de la actividad o de los actos fraudulentos:

«Es el aspecto más importante del fraude [que] consiste concretamente en que el sujeto activo persiga el daño ilícito de otro, como fin real que se sustituye o que transparece a través del fin legal normal del acto realizado, vale decir que hay discordancia entre el fin prefijado por la ley y que objetivamente surgiría del proceso (o del acto procesal) que se efectúa y el que realmente procura el sujeto activo del fraude (defraudador)».

En otro fallo: ${ }^{46}$ se ha indicado que caracterizan al fraude procesal la

44Adolfo Gelsi Bidart, "Noción de fraude procesal», RDJA, Tomo 68, pp. 99-112; también en: Revista de Derecho Procesal Iberoamericana, año 1970 No 1, pp. 7-32, especialmente pp. 31-32.

45 LJU, Tomo 102, Caso No 11747, pp. 461-477, Sentencia del 12/11/1990, del Jdo. Ltdo. de $1^{\text {a }}$ Instancia en lo Civil de $6^{\circ}$ Turno, a cargo del doctor Elías Piatniza. 
coexistencia de cuatro elementos: a) que se produzca un resultado ilícito; b) que el medio utilizado para ello sea una combinación de actos jurídicos que, independientemente considerados, no incurran en ilicitud; c) que tales actos jurídicos se conviertan en actos procesales por medio de un proceso que les sirva de aglutinante; $y \mathrm{~d}$ ) que como consecuencia de una maquinación que acomode los actos al resultado ilícito, se origine una utilización anormal del proceso.

Y se agregaba en la referida sentencia: que solo cuando concurran estas condiciones se estará frente a una hipótesis de fraude procesal, y en ella se definía al fraude procesal como el desplazamiento de vigencia de un imperativo legal logrado por la utilización anormal del proceso.

Véscovi ${ }^{47}$ señala que en la evolución de las ideas existió un primer momento en que se afirmaba que el proceso fraudulento o simulado para obtener un resultado ilegítimo en perjuicio de terceros era nulo y que a éstos cabía pedir la nulidad.

Posteriormente y como un paso adelante se admitió la invalidez del proceso simulado, aun cuando no fuese en perjuicio de terceros (caso de un divorcio en el que se simula una causal, un domicilio, etc.).

Más recientemente, los Código modernos han otorgado poderes al Tribunal para excluir el fraude del proceso, aún cuando este no perjudique a terceros siempre que estén en juego normas de orden público.

En tal sentido resulta oportuno recordar las disposiciones del C.G.P. Art. $5^{\circ}$, arts. $54^{\circ}$ y $24^{\circ} \mathrm{No}^{\circ} 4$ y $8 .^{48}$

46 LJU, Tomo 72, Caso No 8045.

47 Enrique Véscovi, Derecho Procesal Civil, ed. IDEA, T. III (1975), p. 88.

48 C.G.P. Art. $5^{\circ}$, Buena fe y lealtad procesal: - Las partes, sus representantes o asistentes $y$, en general, todos los partícipes del proceso, ajustarán su conducta a la dignidad de la Justicia, al respeto que se deben los litigantes y a la lealtad y buena fe.

El tribunal deberá impedir el fraude procesal, la colusión y cualquier otra conducta ilícita o dilatoria.

C.G.P. Art. 540- Llamamiento de oficio en caso de fraude o colusión: -En cualquiera de las instancias, siempre que se presuma fraude o colusión en el proceso, el tribunal de oficio o a petición del Ministerio Público o de pare, ordenará la citación de las personas que puedan ser perjudicadas para que hagan valer sus derechos, pudiéndose, a tal fin, suspender el proceso hasta por cuarenta días.

C.G.P. Art. 24\%.- Facultades del tribunal:- El tribunal está facultado: [...] 4) Para ordenar las diligencias necesarias al esclarecimiento de la verdad de los hechos controvertidos, respetando el derecho de defensa de las partes; [...]. 


\subsubsection{Las vías de impugnación}

A) El recurso de revisión:

\section{I) Concepto}

Este recurso es una de las vías que es posible utilizar para obtener la revisión de la cosa juzgada y definiéndolo decimos que es: un medio impugnativo extraordinario que habilita, dentro de un determinado plazo, para hacer valer, frente a una sentencia pasada en autoridad de cosa juzgada, determinadas causales de excepción, expresamente previstas en la ley, con la finalidad de obtener la revocación de la resolución impugnada. ${ }^{49}$

II) Naturaleza del recurso

Es un recurso extraordinario, ya que procede contra las sentencias definitivas o interlocutorias firmes que pongan fin al proceso.

Como consecuencia lógica de su naturaleza - recurso extraordinariosu interposición no tendrá efecto suspensivo sobre la resolución firme que le diera motivo. No obstante, se consagra por el C.G.P. la posibilidad de obtener la suspensión de lo decidido, otorgando garantía suficiente y siempre que se den las condiciones previstas en el Art. $289^{\circ}$, a saber: recurso aparentemente fundado y posibilidad de que la demora en el trámite del recurso pueda causar perjuicios graves e irreparables al recurrente.

A diferencia del recurso de casación, el recurso de revisión se concede, en general, frente a determinadas situaciones de hecho, conocidas con posterioridad a la resolución que se impugna, pero las cuales de haberse conocido antes, hubieran sido determinantes para una decisión diferente.

En cuanto a la finalidad del recurso, como señala la doctrina, ${ }^{50}$ este se interpone contra sentencias con aparente cosa juzgada para revocar la resolución impugnada y eventualmente permitir la reproducción del juicio, a efectos de que en el nuevo proceso recaiga una verdadera cosa juzgada (Art. 290\%).

8) Para rechazar in limine la intervención de terceros cuando la petición carezca de los requisitos exigidos.

49 Este concepto ha sido receptado por la sentencia $177 / 99$ dictada por el Tribunal de Apelaciones en lo Civil de ler. Turno, RUDP 4/2000, Suma 585.

50 Santiago Pereira Campos, «El Recurso de revisión y la acción revocatoria en el Código General del Proceso", en: RUDP 3/1990, p. 456 y ss. 
III) Las causales de revisión (C.G.P. Art. 283)

Los motivos de la revisión deben tener un carácter decisivo respecto de la sentencia y, como ya lo hemos señalado, deben constituir una auténtica novedad con respecto al proceso anterior, es decir, tratarse de hechos nuevos y posteriores a la sentencia, o conocidos con posterioridad a la resolución que se impugna, pues de haberse conocido antes hubieran sido determinantes para una decisión diferente.

Análisis de las distintas causales de revisión.

«1. Cuando la resolución se hubiere producido por efecto de la violencia, la intimidación o el dolon.

El Art. $62^{\circ}$ del C.G.P. establece que los actos procesales se presumirán siempre realizados voluntariamente, prevaleciendo la voluntad declarada, salvo disposición en contrario o prueba fehaciente de que ha sido formulada - dicha voluntad - por violencia, dolo o error no culpable, y el Art. $63^{\circ}$ exige, además, que los actos deberán ser lícitos, pertinentes y útiles.

En la causal de revisión que estamos analizando, la voluntad del agente que dicta la resolución se encuentra viciada por la violencia o el dolo, y por ende, el acto en sí mismo no es lícito.

En nuestra opinión la previsión del numeral cinco del Art. $283^{\circ}$ que se refiere a la actividad dolosa del tribunal, declarada por sentencia firme restringe la inteligencia de este numeral 1) al dolo de las partes o de terceros, en cuanto este incida en la resolución, pero sin que exista en dicha hipótesis actividad dolosa del tribunal.

Corresponde señalar que la figura de la «intimidación» expresamente establecida en el numeral $1^{\circ}$ queda comprendida dentro de los conceptos tradicionales de la violencia o del dolo.

"2. Cuando alguna de las pruebas que constituyeren fundamento decisivo de la resolución impugnada, hubiere sido declarada falsa por sentencia firme dictada con posterioridad o bien que la parte vencida ignorase que había sido declarada tal con anterioridad".

Los requisitos que deben darse para que se configure esta causal son los siguientes:

a) La prueba debe constituir fundamento decisivo de la sentencia definitiva o interlocutoria firme, que se impugna con el recurso de revisión. 
b) Dicha prueba debe de haber sido declarada falsa por sentencia pasada en autoridad de cosa juzgada.

c) La sentencia que declara falsa dicha prueba debe de haber sido dictada con posterioridad a la sentencia impugnada, o si es anterior, el recurrente debe de haber ignorado tal circunstancia.

«3. Cuando después de la resolución se recobraren documentos decisivos que no se hubiesen podido aportar al proceso por causa de fuerza mayor o por maniobra fraudulenta de la parte contraria».

En este numeral se distinguen dos situaciones:

* Existencia de una causa de fuerza mayor, en ese caso no existe una conducta ilícita de la contraparte.

* Maniobra fraudulenta de la parte contraria que violando los principios de buena fe y lealtad procesal (Art. $5^{\circ}$ ), imposibilita la aportación de un documento decisivo al proceso.

«4. Cuando la resolución fuere contraria a otra anterior que tuviere entre las partes autoridad de cosa juzgada, siempre que no hubiere recaído pronunciamiento sobre la respectiva excepción».

En nuestra jurisprudencia se han dado casos, por ejemplo, de sentencias de prescripción adquisitiva relativas al mismo inmueble contrarias entre sí. Puede mencionarse al respecto la sentencia 222/81 del Tribunal de Apelaciones en lo Civil de 3er Turno, publicada en la Revista uruguaya de derecho procesal 2/82, Notas 20,21 y 836 .

La Suprema Corte de Justicia en sentencia 250 del 2 de noviembre de 2001, acogiendo un recurso de revisión y anulando la sentencia impugnada, fundamentó su decisión en esta causal en los siguientes términos:

En el presente caso la sentencia impugnada No 54 dictada por la Juez letrado de primera instancia en lo civil de $22^{\circ}$ Turno el 21 de julio de 1993 (que dispuso la entrega del inmueble padrón No 21842 de Montevideo al S.V.B., adquirente del bien en el remate realizado en la ejecución seguida por E.P contra R.M.L.) se opone a la sentencia No 47 dictada por la Juez Letrado de Primera Instancia en lo Civil de $22^{\circ}$ Turno el 16 de octubre de 1995 que declaró la nulidad de todo lo actuado en el referido juicio ejecutivo mencionado y también a la sentencia No 106 dictada por el Tribunal de Apelaciones en lo Civil de $8^{\circ}$ Turno el 16 de junio de 1994 
que dispuso que deberá tenerse por adquirente del bien padrón No 21842 a J.M.L. — causante de los autos— en lugar de R.M.L.

La contradicción sustancial de las decisiones es clara. La Sentencia No 54 que se pretende revisar ordena la entrega del bien a $\mathrm{V}$. en mérito a su calidad de adquirente del mismo en el remate realizado en el proceso declarado nulo por la Sentencia No 47, mientras la Sentencia No 106 declara que R.M.L. - demandada en la ejecución declarada nula y como tal, causante dominial de V. - no era realmente titular del inmueble adquirido por $\mathrm{V}$.

«5. Cuando la resolución se hubiere obtenido por actividad dolosa del Tribunal, declarada por sentencia firme (arts. $114^{\circ}$ y $115^{\circ} .2$ )».

En este caso la conducta ilícita emana del propio tribunal y ella determina una resolución perjudicial para la parte que, a través de esta causal, puede solicitar la revisión del fallo.

No toda actividad dolosa del tribunal habilita la interposición del recurso de revisión, sino que para ello previamente debe haberse declarado dicha actividad como ilícita mediante sentencia que haya adquirido la autoridad de cosa juzgada.

«6. Cuando existiere colusión u otra maniobra fraudulenta de las partes, siempre que hubiere causado perjuicios al recurrente o a la causa pública».

El proceso colusivo que es una de las hipótesis que contempla esta causal es, según Ferrara, "una forma anómala del juicio" que en vez de ser una lucha entre los litigantes, es «una comedia para dañar a terceros».

Gelsi señala que la simulación procesal puede darse tanto de un acto en particular o de una etapa, de un incidente o de un proceso en su integridad, y significa la existencia de un acto o proceso "aparente", «simulado", «representado», por las partes con o sin la complicidad del juez.

Comentando el famoso caso Pecoraino, Carnelutti ${ }^{51}$ señalaba que el fraude bilateral es siempre un fenómeno patológico. Aquí el poder saludable del contradictorio no existe; en los hechos el contradictorio se reduce a una apariencia.

51 Francesco Carnelutti, "Contro il processo fraudolento», en: Rivista di Diritto Processuale Civile, parte segunda, 1926, pp. 14-25. 


\section{Los sujetos}

* Tribunal competente

La competencia corresponde exclusivamente a la Suprema Corte de Justicia, tanto para el análisis de su admisibilidad (Art. 288 ) como para su decisión (Art. 282\%), cualquiera haya sido el grado del tribunal en que hubiese quedado firme la sentencia recurrida.

* Legitimados

De acuerdo a lo dispuesto por el Art. $284^{\circ}$, el recurso puede ser interpuesto:

- por quienes hayan sido partes en el proceso, sus sucesores o causahabientes;

- los terceros en los casos previstos en los numerales 5 y 6 del Art. $283^{\circ}$ (actividad dolosa del tribunal declarada por sentencia firme y los casos de colusión o maniobras fraudulentas de las partes en perjuicio de terceros) ya analizados, siempre que la resolución les causare perjuicio;

- por el Ministerio Público, cuando los hechos invocados afectaren la causa pública, es decir, cuando resultare perjudicado el interés público.

\section{Sentencias impugnables}

Conforme al Art. $281^{\circ}$, el recurso procede contra las sentencias definitivas o interlocutorias firmes que pongan fin al proceso.

Dentro de las definitivas, serán recurribles en revisión, tanto las declarativas así como las constitutivas o de condena.

Dentro de las interlocutorias firmes que ponen fin al proceso se encuentran comprendidas aquellas que acojan alguna de las denominadas excepciones mixtas (prescripción, caducidad, cosa juzgada y transacción) o que declaren que se ha operado la perención de la instancia (C.G.P. Art. $233^{\circ}$ y ss.) o que se ha producido el desistimiento (C.G.P. Art. $226^{\circ}$ y ss.).

Cabe indicar que la norma del Art. $281^{\circ}$ se refiere a las sentencias definitivas o interlocutorias firmes que pongan fin al proceso, dictadas por cualquier tribunal, sin requerirse que sea un tribunal de segunda instancia, como se establece a texto expreso para la casación (C.G.P. Art. $268^{\circ}$ ) y pudiendo, por ende, ser susceptible de revisión una sentencia de primera instancia que haya quedado consentida.

\section{Trámite del recurso}

* Interposición. Requisitos

El recurso se presentará ante la Suprema Corte de Justicia en escrito que deberá contener con precisión sus fundamentos - de hecho y de de- 
recho- y agregarse toda la prueba conforme a lo establecido para la demanda (arts. $117^{\circ}$ y $118^{\circ}$ ).

* Plazos

Máximo de un año desde que hubiere quedado ejecutoriada la resolución impugnable.

Dicho plazo quedará suspendido desde el momento en que se promueva el correspondiente proceso para la justificación del motivo de la revisión, en los casos en que tal proceso fuere necesario, hasta el dictado de la sentencia que ponga fin a dicho proceso.

La revisión tampoco será admisible transcurridos tres meses desde que el recurrente hubiere conocido o debido conocer los motivos en que se fundare la misma.

* Efectos de la interposición del recurso (Art. 2870)

En principio no suspende la ejecución de la resolución firme que lo motivare.

No obstante el recurrente puede pedir la suspensión de los efectos aún pendientes de la resolución impugnada (Art. 289\%).

La Suprema Corte podrá disponer la suspensión si de las circunstancias resultare el aparente fundamento del recurso, así como la posibilidad de que la demora del trámite pudiere ocasionar perjuicios graves e irreparables al recurrente, quien deberá prestar garantía suficiente a juicio de la Corte.

* Procedimiento del recurso

Interposición: en escrito fundado y con prueba ante la Suprema Corte de Justicia.

Examen de admisibilidad:

-Suprema Corte - rechaza - fin del procedimiento.

-Suprema Corte admite:

-ordena al tribunal donde se encuentra el proceso que lo remita en el plazo máximo de diez días;

-dispone el emplazamiento a cuantos hubieren litigado en el pleito o a sus sucesores o causahabientes, para que comparezcan a contestar el recurso en el plazo de treinta días.

Prosecución posterior conforme al procedimiento de los incidentes (Art. 3210). 
La Suprema Corte ordenará el diligenciamiento de la prueba que debió presentarse con el recurso (Art. 286 $)$ o su contestación y la concentrará en una sola audiencia, al término de la cual oirá brevemente a las partes acerca del resultado de la misma.

Sentencia que resuelve el recurso (Art. 290)

Caben dos posibilidades:

a) Si lo rechaza finaliza el procedimiento

b) Si acoge el recurso por estimar fundada la revisión, así se declarará y se revocará la resolución impugnada, en todo o en parte, según proceda, mandándose expedir certificación del fallo para que las partes puedan reproducir el proceso, si ello conviniere a su derecho.

Las conclusiones de la sentencia de revisión que no podrán ser discutidas ni modificadas, servirán en todo caso de base al nuevo proceso.

Frente a la sentencia que decide el recurso, ya sea que lo acoja o que lo rechace, solo serán procedentes los recursos de aclaración y de ampliación previstos en el Art. $244^{\circ}$.

* Efectos del recurso respecto de los terceros de buena fe.

El Art. $290^{\circ}$ in fine dispone que "Será aplicable a lo decidido en revisión lo dispuesto en el Art. $375^{\circ} .4 "$ y esta última norma establece que:

«En ningún caso la revocación y la casación podrán perjudicar a terceros de buena fe, ni determinar la anulación de los actos o contratos celebrados con el dueño aparente de los bienes".

* Gastos del recurso (Art. 292\%)

Si el recurso es rechazado impondrá las costas y costos al recurrente.

Si es acogido, la Suprema Corte condenará preceptivamente al vencido si este hubiera tenido participación en los hechos determinantes de la revocación de la sentencia.

En los demás casos, la imposición de las costas y costos se determinará según las circunstancias.

B) La acción autónoma de revisión de la cosa juzgada

1) Su admisión antes de la vigencia del Código general del proceso:

Como ya lo hemos señalado, ${ }^{52}$ tanto la doctrina como la jurispruden- 
cia habían admitido la posibilidad de una acción autónoma para la revisión de las sentencias obtenidas mediante dolo, fraude, colusión o en casos de indefensión.

2) Los supuestos de la revisión

\subsection{El fraude:}

El «leading case» en nuestro país fue la sentencia dictada por Gualberto Pi el $1^{\circ}$ de noviembre de $1942^{53}$ y que Couture en su estudio «La revocación de los actos procesales fraudulentos ${ }^{34}$ lo relatara así:

Un hombre de sólida fortuna, propietario rural, había tenido un hijo natural como fruto de sus relaciones íntimas con una persona de su servicio. Procurando hacer desaparecer las consecuencias jurídicas y económicas de aquel hecho, logró que la madre del menor diera mandato a una persona de confianza del padre, la que aceptó la consigna de promover un juicio de investigación de la paternidad contra el padre. Bajo la dirección, no aparente, de la misma persona, el padre compareció a defenderse, negando la verdad de los hechos relatados en la demanda.

Abierto el juicio a prueba, el apoderado de la madre lo dejó transcurrir deliberadamente sin producir prueba alguna. La sentencia, forzosamente, rechazó la demanda de investigación de la paternidad. Muchos años después, llegado el hijo a la mayoría de edad, promovió demanda de investigación de la paternidad contra su padre y contra ella se opuso la excepción de cosa juzgada.

En la excelente sentencia que rechazó con sólidos argumentos dicha excepción, el magistrado Pi señaló, entre otras consideraciones: ${ }^{55}$

"Los antecedentes de nuestra legislación, su espíritu y los principios que la informan, dan perfectamente cabida a la acción revocatoria». Ya destacó con exactitud el doctor Couture que:

53 La justicia uruguaya, Tomo 6, No 1337.

54 Eduardo J Couture, Estudios de Derecho Procesal, Ed. Depalma, Tomo III, p. 385 y ss.; también en: La Ley, Tomo 16, p.104 y ss. y en: RDJA, Tomo 38, p. 13 y ss.

55 LJU, Tomo 6, Caso No 1337, pp. 257-258. 
«el instituto de la oposición a la cosa juzgada fraudulenta no aparece en nuestra ley, no porque haya sido repudiado sino simplemente porque no ha sido previsto por el legislador».

«El fraude, la colusión o el dolo, medio por el que las personas se apartan de las finalidades lícitas en sus relaciones jurídicas, son fenómenos anormales en el ámbito de las convenciones privadas como en el proceso civil».

"Por eso el legislador se preocupó especialmente de combatirlo».

«En el primer aspecto adoptó instrumentos de probada eficacia: acciones in rem verso, simulación pauliana, subrogatoria, anulación en la quiebra, etcr.

«En lo relativo a la fase procesal, estableció los recursos, excepciones, incidentes de nulidad, juicio ordinario posterior, etc.”

«Pero todos estos últimos son elementos que integran la técnica normal de la mayoría de los procesos».

«Nada previó para el caso extraordinario del ya concluido, cuando dicho instrumental no es más aplicable ni tiene eficacia alguna».

"Es entonces que ante esta situación anormal la técnica concurrió a solucionarla con el instituto de la acción mere declarativa».

«Constituye ésta una de las formas más elevadas y delicadas de actuar del Poder Judicial".

"Puso así en manos de los particulares un instrumento enérgico y eficaz, apto para esclarecer todo estado de incertidumbre jurídica conducente a una sentencia que al decir del doctor Carnelli, especifica, destaca e ilumina, conceptos esfumados en la vaga sombra de lo incierto o de la equivocidad".

"Actualmente su procedencia se considera indiscutible y la jurisprudencia la ha aceptado reiteradamente, en especial en materia de prescripción treintenaria». ${ }^{56}$

«A esta clase pertenece también la de revocación de la cosa juzgada fraudulenta."

"Funciona contra las sentencias obtenidas mediante fraude, colusión o dolo y que perjudican a terceros que no intervinieron en el juicio». "Se apoya en principios análogos a los de la acción pauliana». "Per-

56 Carnelli, Cuestiones de P. Civil, op.cit., p. 237 y ss.; Couture, La acción declarativa de prescripción, p. 32 y ss. y Fundamentos del Derecho Procesal Civil, p. 174, No 140.

57 Eduardo J. Couture, La acción revocatoria, p. 27 y ss.; Revista de la Escuela nacional de Jurisprudencia de México, tomo 3, p. 337 y ss.). 
sigue el reconocimiento por la justicia de que la supuesta cosa juzgada ha quedado sin efecto en razón de vicios que invalidaron el juicio anterior". ${ }^{58}$

"También la doctrina de la inexistencia de los actos procesales, representa una contribución esencial a la admisibilidad de la revocatoria". "Actos inexistentes son aquellos a los que les falta un elemento indispensable en su formación de tal manera que, en su ausencia, no pueden ser concebidos sino al solo título de simples actuaciones judicialesn.

«La inexistencia se refiere a la vida misma de los actos, representa el no ser y es además independiente de toda declaración judicial, pues aquellos carecen de todo efecto y sobre ellos nada puede construirse». 59

«Pertenecen a esta clase de actos los que se desarrollan en el curso de un juicio obedeciendo a las directivas y ejecución de una sola de las partes, después de ser neutralizado quien debió ser contrario, sea por propia connivencia de este, sea por aprovechamiento de su inferioridad psicológica».

"En ese caso, solo existiría la engañosa apariencia de un juicio».

«Pero en el fondo, este no habría llegado realmente a existir por faltar el indispensable choque de dos voluntades contrarias para obtener una decisión sobre una causa o punto controvertido (Art. $1^{\circ}$ y $450^{\circ}$ del Código de Procedimiento Civil)».

«La intervención del Juez aparecería solicitada indebidamente, no con el propósito de solucionar una contienda, sino para encubrir fines ilícitos, con su supuesta sentencia».

«Se trataría pues, de una serie de actos sin valor e incapaces de producir efectos".

«Pero a veces la cuidadosa preparación de las partes o el transcurso del tiempo les da una engañosa apariencia de acto jurídico verdadero, una indebida estabilidad".

58 Revista D.P.P., Tomo I, No 23, p.146.

59 Manual Gallinal, tomo 2, p. 258; Eduardo J. Couture, Fundamentos, op.cit., pp. 190, 225 y 238; Sayagués Laso, Recurso extraordinario de nulidad notoria, p. 126, No 84; Díaz, Cosa juzgada, p. 8, No 4; Revista del Instituto de jubilaciones y pensiones del Uruguay, año 6, p. 125, No 46, y Revista de estudios jurídicos y sociales, Año 9, p. 118. 
"Entonces se hace necesaria la intervención de la Justicia, no propiamente para declarar la inexistencia desde que no hay situación jurídica, sino para quitar al acto su falsa apariencia y hacerla de todos conocida".

"La forma de actuar es mediante el instrumental de la acción declarativa".

"Su resultado será una sentencia igualmente declarativa, que constará que ese acto, juicio o sentencia de que quiere aprovecharse una de las partes, se halla desprovisto de todo contenido real o eficiente ${ }^{60}$ "El dinamismo y la energía de la acción declarativa, que la lleva a agotar sus fines y cumplir su destino, no puede ser detenido por la excepción de cosa juzgada».

"Se ha dicho que la cosa juzgada es un instrumento indispensable de paz, seguridad y justicia, en las relaciones jurídicas de los hombres». "De ahí que las legislaciones nieguen casi sistemáticamente toda acción de nulidad, promovida por separado, después de concluido un proceso". ${ }^{61}$

"Pero ante el proceso colusorio, en verdad, el principio de la inmutabilidad de la cosa juzgada se desplaza, por la alteración solapada de las finalidades del Instituto, y deja de ser estrictamente correcto colocarlo en oposición irreductible e irreconciliable con el de la acción declarativa».

«Cuando no ha habido verdadero juicio y la sentencia es el producto del engaño delictual, entonces no puede técnicamente hablarse de cosa juzgada sino solamente de una máscara o mera apariencia».

"Invocarla en tal caso equivaldría a admitir que la teoría de los actos ilícitos es una ilusión y que el proceso es un campo neutral que protege y encubre el fraude y el dolo". ${ }^{62}$

"Se contribuiría así a establecer el predominio de las meras fórmulas sobre la realidad, a someterse a su tiranía y a caer en fetichismo y absurdas exageraciones, según las cuales "hace lo blanco negro, produce el origen de las cosas, cambia lo cuadrado en redondo, cambia los neutrales vínculos de la sangre y lo que es falso en verdad» (Couture: La acción revocatoria, página 20)». 
«En materia procesal es también cierto que los actos se juzgan por su real contenido y no por el nombre que jamás haya convenido darles a las partes".

«Por eso, una vez constatado el fraude nada importa el ropaje con que se hubiere vestido, aunque sea el de la cosa juzgada; el traje debe ser aventado para dejar al fraude en descubierto o impedirle la producción de efectos engañosos».

En otro caso ventilado ante nuestros tribunales ${ }^{63}$ se utilizó un proceso de prescripción en el que se hizo un emplazamiento genérico viciado, ya que el actor conocía la existencia, identidad y domicilio de quienes debían ser emplazados.

Con dicho proceso se procuró por el legatario —en abierto fraude a la voluntad del causante- evadir el cumplimiento del modo o condición impuesto por el testador.

Se utilizó como causa del proceso prescriptivo en apariencia la que fija la ley, pero en la realidad, se le usó como medio fraudulento para obtener un nuevo modo de adquirir el dominio (prescripción) que le permitiera eludir la disposición testamentaria que le impedía enajenar los bienes.

Dichos vicios aparejaron: la anulación del proceso de prescripción por fraude e indefensión, la resolución del legado establecido en el testamento a favor de quien actuó con ánimo fraudulento y a vía de consecuencia el acrecimiento de las cuotas partes de los restantes herederos y el posterior reparto entre ellos de dichos bienes.

- Naturaleza excepcional de la revocación

Si en nombre del fraude se pudieran reabrir todos los procesos culminados en cosa juzgada, los fines de paz, de orden y de seguridad jurídica que ésta persigue habrán desaparecido. Se plantea la duda Couture ${ }^{64}$ y acto seguido nos da la respuesta:

«Es evidente que el fraude y la colusión no siempre aparecerán nítidamente. Hay extensas zonas limítrofes, imprecisas. Es toda esta materia una cuestión de hecho; y en muchas oportunidades de circunstancias subjetivas que quedan libradas a la apreciación de los

$63 \mathrm{LJU}$, Tomo 102, Caso No 11.747, pp. 461-472, con nota de los profesores Eduardo Vaz Ferreira y Hortensia Ramos Mañé. 
jueces. Puede decirse que la doctrina está edificada sobre las situaciones claras; en los casos confusos, en las situaciones en las cuales los límites de la licitud y la ilicitud sean dudosos, el magistrado se abstendrá de anular la cosa juzgada».

\section{$2.2 \mathrm{La}$ indefensión}

Este supuesto de la revisión se da —entre otros casos posibles - cuando exista un vicio en el emplazamiento, ya sea porque no se notificó al demandado, o se le notificó en un domicilio erróneo, o se le emplazó por edictos cuando se le conocía en su identidad física y en su domicilio, o se notificó a persona fallecida o a quien carece de capacidad o no tiene la representación del legitimado pasivo.

En estas hipótesis, tanto la doctrina como la jurisprudencia admitieron la vía de la acción autónoma de nulidad de la sentencia así obtenida, la que había adquirido la autoridad de la cosa juzgada en forma aparente. Si el proceso había finalizado la vía era la del proceso ordinario y la incidental si el proyecto aún no había concluido.

Gelsi Bidart ${ }^{65}$ y la jurisprudencia ${ }^{66}$ siguiendo a dicho autor distinguieron entre la acción revocatoria por fraude en que es necesario probar el elemento subjetivo, de la nulidad por indefensión, en que basta demostrar el hecho objetivo del vicio en el emplazamiento, esto es, la ausencia de emplazamiento o la indebida notificación, aún cuando ella no derive del dolo o la mala fe, que no es necesario probar en este caso para perseguir la nulidad.

Al respecto la jurisprudencia uruguaya ${ }^{67}$ en el sentido indicado sostuvo que:

"Las dos acciones, la revocatoria y la de nulidad no pueden confundirse ni asimilarse. Para ésta última basta acreditar el hecho del no

64 Eduardo J. Couture, Estudios[...], Tomo 3, op.cit., pp, 391 y 401-402.

65 Adolfo Gelsi Bidart, "De las nulidades en los actos procesales” y en: "Bases positivas para la noción de cosa juzgada», Estudios jurídicos en memoria de Eduardo J. Couture, 1957, pp. 341-361.

66 LJU, Tomo 75, Caso No 8614.

${ }^{67}$ LJU, Tomo 75 Caso No8614, Sentencia de fecha 23 de agosto de 1976, Tribunal de Apelaciones en lo Civil de ler. Turno integrado por García Otero (R), Gatto de Souza y Olmedo. 
emplazamiento, la constatación objetiva de que el reo no fue «debidamente" llamado al juicio, sin que se requiera investigación alguna sobre el elemento subjetivo que condujo a ese resultado".

Como dice Gelsi Bidart ${ }^{68}$ : «basta eliminar el supuesto objetivo de la cosa juzgada, el juicio regular o válido, para que ella desaparezca; descartado el soporte de la cosa juzgada ésta también se aniquila. No importa que el actor que gestionó mal el emplazamiento del reo (configurándose su no emplazamiento) haya sido diligente, procediera con culpa o con intención aviesa, el no llamamiento regular del reo al juicio conduce siempre a la nulidad porque solo hay una apariencia de proceso.

En cambio, el soporte de la revocación por fraude es otro, la imputación debe ser seguida de la prueba del elemento subjetivo, el ánimo de engañar, para que la acción reciba amparo».

\subsection{Hipótesis en que el tribunal haya actuado con absoluta incompetencia o falta de jurisdicción}

En estos casos la doctrina nacional también admitía la posibilidad de una acción revocatoria autónoma siguiendo en este aspecto los lineamientos del derecho comparado.

\subsection{Vía procesal a utilizar}

$\mathrm{Al}$ respecto no existía coincidencia tanto en la doctrina como en la jurisprudencia en cuanto al procedimiento a utilizar, ya que la mayoría, siguiendo a Couture y Véscovi, se inclinaba por la acción declarativa autónoma tramitada en proceso ordinario y la tesis minoritaria sustentada por el Tribunal de Apelaciones en lo Civil de Tercer Turno y Torello se inclinaba por la vía incidental, argumentando que el proceso no podía considerarse terminado, si por emplazamiento defectuoso o falta de él, había existido indefensión y por ende no había existido el debido proceso requerido por la Constitución y la ley.

68 Gelsi Bidart, «Bases positivas para la noción de cosa juzgada», en: «Estudios jurídicos en memoria de E.J. Couture", 351, ratificando lo que expresara antes en: De las nulidades en los actos procesales, pp. 353-355. 


\subsection{Plazo para deducir la acción}

Se ha entendido, que al no existir plazo expresamente establecido al efecto, regía el de la prescripción de los derechos conforme a las reglas generales.

\subsection{Naturaleza de la sentencia}

La mayoría de la doctrina y de la jurisprudencia afirmaba la naturaleza declarativa de la sentencia que hacía lugar a la acción autónoma de nulidad por indefensión o la que disponía la revocación por fraude. Corresponde poner de relieve que siempre se han resguardado los derechos de los terceros adquirentes de buena fe de los bienes que integraban el objeto del proceso.

3) La acción autónoma de revisión de la cosa juzgada luego de la vigencia del Código General del Proceso

\subsection{Introducción}

El punto fundamental radica en determinar si la posibilidad de proceder a la revisión de la cosa juzgada está limitada a las causales y plazos del recurso de revisión (arts. $281^{\circ}$ a $292^{\circ}$ C.G.P.) o si en casos excepcionales de indefensión, dolo, fraude o colusión puede admitirse una acción autónoma de revisión de la cosa juzgada.

\subsection{La relatividad de la cosa juzgada}

Hemos señalado antes, que compartimos la posición sustentada por la doctrina procesal contemporánea ${ }^{69}$ que tiende a dar a la noción de cosa

69 Juan C. Hitters, Revisión de la cosa juzgada, Librería Editora Platense, op cit., p.192; Roberto Berizonce, Cosa juzgada fraudulenta y acción de nulidad, JUS editora Platense, V.10, p. 78; Candido Dinamarco, "Relativizar a coisa julgada material", en:Congreso brasileño de derecho procesal, también en: Cuadernos Procesales, Organo de divulgación del Colegio de Profesores de Derecho Procesal de la UNAM, México, No 14, diciembre, 2001.

Santiago Pereira, "El recurso de revisión y la acción revocatoria», en: RUDP, 3/1990, pp. 456-473. 
juzgada un valor relativo, que si bien es importante a los fines de la paz, el orden y la seguridad jurídica en un conglomerado social determinado, de ninguna manera puede considerársele como un valor absoluto.

En los casos excepcionales que hemos indicado —dolo, fraude, colusión e indefensión — detectados aún después del plazo de un año — máximo admitido por nuestro recurso de revisión - consideramos que es posible deducir una acción autónoma dirigida a revisar la aparente cosa juzgada, pues, mediante dicha acción se apunta a destruir los efectos de una sentencia que de cosa juzgada solo tiene el nombre, dado que en el fondo no es más que el fruto espúreo del dolo, del fraude, de la connivencia ilícita o de la indefensión.

Como lo señalara Couture: ${ }^{70}$

«Si se cierra la vía de la acción revocatoria, el fraude procesal y aún las formas delictuosas del proceso, adquieren carta de ciudadanía y carácter legítimo. La máxima fraus omnia corrumpit carecerá ya de aplicación, porque una envoltura de cosa juzgada purifica todos los vicios de los actos jurídicos».

\subsection{Los textos legales del Código General del Proceso}

C.G.P. Art. $114^{\circ}$ - Anulación de los actos procesales fraudulentos.

"Podrá pedirse, aún después de terminado el proceso, la anulación de los actos procesales realizados mediante dolo, fraude o colusión».

Esta anulación podrá pedirse solo por aquellos a quienes el dolo, fraude o colusión han causado perjuicio, y de acuerdo con los principios mencionados en los artículos anteriores. Los terceros pueden también solicitar esta anulación. Si los actos fueren anulados, se repondrán las cosas en el estado anterior de los mismos.

C.G.P. Art. $15^{\circ}{ }_{-}$«Vías procesales para la reclamación de la nulidad. $115^{\circ} .1$ - La nulidad que afecta a la demanda principal o incidental se debe reclamar por vía de excepción o de defensa, al contestarla.

70 Eduardo J. Couture, «La acción revocatoria de la cosa juzgada fraudulenta», en: RDJA Tomo 38, pp. 13-21 y también en: La Ley, Secc. Doc., Tomo 16, p. 104 y ss., citado por Juan C. Hitters, Revisión de la cosa juzgada, op.cit., p. 257. 
$115^{\circ} .2$ - La nulidad que afecta a los actos procesales recurribles se debe reclamar por vía del recurso de reposición y por el de apelación, cuando este correspondiere, así como por el de revisión en los casos previstos por el Art. $114^{\circ}$.

115\%.3- Procede reclamar la nulidad por vía de demanda incidental cuando, sea por la naturaleza del acto, sea por otra circunstancia, no corresponda o haya sido imposible hacerlo por vía de recursos o excepción; en tal caso la demanda incidental, deberá ser deducida dentro de los veinte días siguientes al del conocimiento fehaciente del acto».

C.G.P. Art. $129^{\circ}$ - Sanción por omisión.

$129^{\circ} .1$ - La omisión o alteración de las formas del emplazamiento apareja la nulidad insanable del mismo.

$129^{\circ} .2$ - No existirá nulidad, si la forma utilizada ofreciera al emplazado las mismas o más garantías que las que este Código establece.

$129^{\circ} .3$ - Tampoco podrá reclamarse la nulidad por quien ha comparecido en el proceso sin plantearla dentro de los plazos legalmente establecidos al efecto, ni por quien se pruebe que ha tenido conocimiento fehaciente del proceso y omitido reclamar la nulidad dentro del plazo acordado (Art. 115').

C.G.P. Art. $221^{\circ}$ - Efectos de la cosa juzgada en procesos con emplazamiento a personas indeterminadas o inciertas.

En los procesos en que hayan sido emplazadas como demandadas personas indeterminadas o inciertas, la sentencia surtirá efecto en relación a todas las personas comprendidas en el emplazamiento, salvo que se compruebe en el mismo proceso o en otro, que su identidad sea conocida por alguna de las partes y sin perjuicio de los derechos adquiridos por terceros de buena fe.

\subsection{Los diversos casos que se pueden plantear}

La doctrina uruguaya ${ }^{71}$ ha individualizado determinadas situaciones y ha dado su respuesta a las mismas. Con algunas coincidimos, con otras formularemos nuestras discrepancias.

71 Santiago Pereira Campos, El recurso de revisión y la acción [...], op.cit., pp. 471473. Dicho autor ha sido seguido casi a la letra por E. Véscovi y colaboradores en: Código General del Proceso, Tomo 2, pp. 456-458 y 464-467. 
A) Situaciones que encuadren en alguna de las causales del recurso de revisión del Art. $283^{\circ}$, pero que se conocen luego de transcurrido el plazo de caducidad de un año previsto en el Art. $285^{\circ} .1$.

En esta hipótesis, Pereira Campos ${ }^{72}$ si bien no coincide con la solución legal, estima que de acuerdo con el Art. 285 .1, transcurrido dicho plazo, tratándose de una circunstancia que configure causal de revisión (Art. 283으, la cosa juzgada se vuelve inmutable.

Dicho autor considera que sostener una tesis contraria, llevaría a dejar sin aplicación el plazo fijado, lo que carecería de todo sustento.

En nuestra opinión, en este caso es posible fundar la tesis contraria en favor de la admisibilidad de la acción autónoma.

Nos basamos para ello en que la Constitución y los tratados internacionales suscritos por el país han consagrado la garantía del debido proceso y el Art. $98^{\circ}$ del C.G.P. ha establecido especialmente el principio general de que:

«Al impedido por justa causa no le corre plazo desde el momento en que se configura el impedimento y hasta su cese. Solo se considera justa causa la que provenga de fuerza mayor o caso fortuito para la parte y que la coloque en la imposibilidad de realizar el acto por sí o por mandatariom.

Con un ejemplo trataremos de demostrar nuestra tesis. Así, si en un proceso la sentencia favorable al actor se produjo en virtud de la incomparecencia del demandado, en aparente rebeldía, y ésta, en la realidad de los hechos, se debió al secuestro del reo por parte del actor, aunque en la especie se haya configurado - en virtud del dolo- la hipótesis del Art. $283^{\circ}$ No $^{\circ}$, nos resulta indubitable que la acción autónoma será admisible aún cuando haya transcurrido el plazo de un año.

Lo mismo ocurriría — en otra hipótesis - si el actor en un proceso de prescripción adquisitiva hubiese dolosamente sustraído del domicilio del demandado todos los cedulones que le daban noticia del proceso y este recién se entera - transcurrido más de un año—al extraer los correspondientes certificados de los Registros de la Propiedad cuando estaba procediendo a la venta de dicho bien.

72 Santiago Pereira Campos, El recurso de revisión [...], op.cit., p. 472. 
B) Situaciones no contempladas por las causales de revisión pero que configuran situaciones de indefensión.

*Por violaciones graves de las garantías del debido proceso que puedan ocurrir por múltiples circunstancias.

*Por violación a las normas que regulan el emplazamiento que son sancionadas con la nulidad insanable (C.G.P. Art. 129\%.1).

*La del impedido por justa causa (fuerza mayor o caso fortuito) - C.G.P. Art. $98^{\circ}$.

En estas situaciones Pereira Campos, en solución que compartimos, admite también la revisión de la cosa juzgada aparente.

\subsection{Vías procesales a utilizar para la acción de revisión de la cosa juzgada fraudulenta o aparente.}

En las situaciones que hemos individualizado con la letra $\mathrm{A}$ y respecto de las cuales admitimos la posibilidad de una acción declarativa de revisión de la cosa juzgada fraudulenta ${ }^{73}$ entendemos que dada la amplitud de la previsión normativa consagrada en el Art. $114^{\circ} \mathrm{del}$ C.G.P. la vía procesal a utilizar es la del proceso ordinario.

En efecto, dicha estructura procesal es la prevista por el legislador (C.G.P. Art. $348^{\circ}$ ) para tramitar "[...] todas aquellas pretensiones que no tengan establecido un proceso especial para su sustanciación".

Por otra parte, el proceso ordinario es el que ofrece mayores garantías y da más posibilidades para probar el elemento subjetivo (dolo, fraude, colusión) requerido para el éxito del accionamiento por nuestra doctrina y jurisprudencia clásica.

En apoyo de nuestra tesis invocamos la previsión contenida en el Art. $221^{\circ}$ del C.G.P. que dispone: «efectos de la cosa juzgada en procesos con emplazamiento a personas indeterminadas o inciertas».

En los procesos en que hayan sido emplazadas personas indeterminadas o inciertas, la sentencia surtirá efecto en relación a todas las personas comprendidas en el emplazamiento, salvo que se compruebe en el mismo proceso o en otro, que su identidad sea conocida por alguna de las partes $y$ sin perjuicio de los derechos adquiridos por terceros de buena fe. ${ }^{74}$

73 En contra, S. Pereira Campos, El recurso de revisión y la acción [...], op.cit., pp. 471-472.

74 Véase sentencia No 66 del TAC de $2^{\circ}$ Turno, con nota de Walter Guerra Pérez, "Emplazamiento genérico: cuándo procede», en: RUDP 1/99, pp. 143-150. 
Si conociendo la identidad física del futuro demandado se realizara fraudulentamente un emplazamiento genérico por edictos, no nos cabe duda que dicho emplazamiento sería nulo y podría ser atacado en la oportunidad correspondiente con los medios impugnativos previstos en el Art. 115: excepción o defensa; recursos: reposición, apelación, casación, ${ }^{75} \mathrm{re}-$ visión y el incidente de nulidad del Art. $115^{\circ} .3$ que también constituye un medio impugnativo (C.G.P. Art. 243.2).

Corresponde destacar que aun cuando ya estuviere concluido el proceso y hubiese vencido la posibilidad de plantear el recurso de revisión, cabría como vía de impugnación la del "otro proceso" a la que remite el referido Art. $221^{\circ}$ del C.G.P., que en nuestro opinión, debiera ser el proceso ordinario revisivo de esta cosa juzgada obtenida en forma fraudulenta.

En los supuestos referidos en el apartado B, en cambio, el codificador parece haberse inclinado hacia la vía incidental, cuya demanda respectiva deberá ser deducida dentro de los veinte días siguientes al del conocimiento fehaciente del acto que se impugna (C.G.P. arts. $115^{\circ} .3$ y 129 .3 ).

- La situación de los terceros de buena fe.

El legislador uruguayo ha tenido especial cuidado en tutelar los derechos de los terceros de buena fe.

Así, el Art. $290^{\circ}$ en lo referente al recurso de revisión, el Art. $221^{\circ}$ que regula los efectos de la cosa juzgada en procesos con emplazamiento genérico y el Art. $375^{\circ} .4$ que regula la revocación o la casación de la sentencia que hizo lugar a la ejecución provisoria, expresamente establecen que no se puede perjudicar a los terceros de buena fe ni determinar la anulación de los actos o contratos celebrados con el dueño aparente de los bienes.

Por dicha razón y a los efectos de impedir que se pueda alegar la calidad de tercero de buena fe, será muy importante hacer jugar los mecanismos legales que permitan hacer efectivas y eventualmente incorporarlas a un registro, aquellas medidas que signifiquen una traba para la disponibilidad de los bienes en litigio cualquiera sea su naturaleza.

Por su parte, el tercero que quiera acreditar su buena fe por una razón de prudencia elemental procederá a solicitar a los correspondientes registros públicos la expedición de los respectivos certificados de los que resulte que no existe ninguna medida que obste a la operación que se proyecta realizar.

75 No contemplado expresamente en la norma, pero admisible. 
Con relación a la alegada buena fe de un acreedor hipotecario fraudulento, nuestra jurisprudencia ha indicado ${ }^{76}$ que la buena fe supone una conducta diligente, conducta no observada por dicho acreedor hipotecario. Así, no es normal que los antecedentes del bien, a excepción de los dos últimos títulos, fueran fotocopias simples de las matrices, ni aún de las primeras copias, y que la fotocopia de los planos lo fueran de los que están en las diversas oficinas públicas. A cualquier profesional medianamente diligente debía habérsele planteado la interrogante de por qué, no siendo el inmueble una unidad de propiedad horizontal o sin haber existido partición previa, no se le entregaba a dicho acreedor hipotecario toda la titulación y planos originales y, cuando menos, debió haberse corroborado su existencia. El actuar desprolijo del escribano, no puede alegarse como generador de buena fe, máxime cuando aquel intervenía habitualmente en operaciones de préstamos hipotecarios, era el profesional del acreedor hipotecario y tratándose el mutuario señor YY de un perfecto desconocido que se había contactado con el acreedor hipotecario a través del señor ZZ quien operaba como intermediario para la obtención de préstamos publicitando su tarea a través de la prensa escrita.

Existió, además, otro hecho llamativo: la inscripción de las dos compraventas falsas en la misma fecha (25/4/91). Nótese que no se trataba en la especie de un negocio económicamente despreciable y sabidas son las consecuencias de la falta de inscripción dentro del plazo legal (arts. $12^{\circ} \mathrm{y}$ $13^{\circ}$ Ley No 10.793), por lo que esta situación unida a la peculiaridad de los antecedentes dominiales requerían una conducta más diligente que la empleada.

A ello se sumó - se expresa en la sentencia- que no se solicitó al presunto propietario que les exhibiera el inmueble por lo que solamente se lo vio por fuera, ni se requirieron informes del comportamiento comercial de un desconocido futuro deudor.

La sentenciante llegó a la conclusión de que la buena fe del acreedor hipotecario no se probó en dicho proceso.

76 Sentencia del 24 de mayo de 1994 del Jdo. Ltdo. de Primera Instancia en lo Civil de $15^{\circ}$ Turno, a cargo de Nilza Salvo, en: RUDP 1/1994, pp. 81-87, con nota de Luis Alberto Viera. 


\section{Conclusiones}

1. La cosa juzgada es un instrumento indispensable de paz, seguridad y justicia en las relaciones jurídicas de los hombres, pero no es un valor absoluto sino relativo. La necesidad de firmeza de las decisiones judiciales debe ceder, en determinadas circunstancias que ocasionen grave perjuicio, ante la necesidad de tutelar a la verdad como contenido intrínseco del valor justicia.

2. La revisión debe ser excepcional, ya que, la cosa juzgada y su consecuencia la seguridad jurídica, siguen siendo pilares fundamentales del estado de derecho.

3. La admisibilidad de la acción de revisión está edificada — como afirmaba Couture - sobre situaciones claras; en los casos confusos, el magistrado deberá abstenerse de anular la sentencia pasada en autoridad de cosa juzgada.

4. La finalidad de la revocación será, en lo esencial, reparar el perjuicio causado por el dolo, el fraude, la colusión o la indefensión. En principio, donde no exista perjuicio no habrá revocación; no obstante, en aquellos casos en que estén en juego normas de orden público la revocación será procedente aun cuando no exista perjuicio de los terceros.

5. El recurso de revisión, el incidente de nulidad y la acción autónoma son los medios impugnativos a utilizar para obtener la revisión de la cosa juzgada aparente o fraudulenta.

6. Corresponderá acudir a la acción autónoma de revisión de naturaleza declarativa y a tramitar por proceso ordinario, solo en aquellas hipótesis en que no haya sido posible utilizar otro medio impugnativo.

7. La consagración en el Código general del proceso así como en el proyecto de código modelo para Iberoamérica del incidente de nulidad y del recurso de revisión que tiene plazos de interposición y causales específicas, no impiden que se pueda plantear en forma excepcional la acción autónoma hasta el momento en que se haya operado la prescripción de los derechos.

Cerrar la vía de la acción revocatoria implicaría que el fraude procesal y aun las formas delictuosas del proceso pudieran adquirir carácter legítimo, porque una envoltura de cosa juzgada aparente estaría purificando los vicios de los actos jurídicos irregulares, dolosos of fraudulentos. 